Article

\title{
Combining Evapotranspiration and Soil Apparent Electrical Conductivity Mapping to Identify Potential Precision Irrigation Benefits
}

\author{
Mallika A. Nocco ${ }^{1,2, *(\mathbb{D}, \text { Samuel C. Zipper }}{ }^{3}{ }^{(0)}$, Eric G. Booth ${ }^{4,5}$, Cadan R. Cummings ${ }^{6}$, \\ Steven P. Loheide II ${ }^{5}$ and Christopher J. Kucharik ${ }^{1,4}$ \\ 1 Nelson Institute Center for Sustainability and the Global Environment, University of Wisconsin-Madison, \\ 1710 University Ave., Madison, WI 53726, USA; kucharik@wisc.edu \\ 2 Department of Land, Air, and Water Resources, University of California, Davis; One Shields Avenue, Davis, \\ CA 95616, USA \\ 3 Kansas Geological Survey, University of Kansas, 1930 Constant Ave, Lawrence, KS 66047, USA; \\ samzipper@ku.edu \\ 4 Department of Agronomy, University of Wisconsin-Madison, 1575 Linden Dr., Madison, WI 53706, USA; \\ egbooth@wisc.edu \\ 5 Department of Civil and Environmental Engineering, University of Wisconsin-Madison, \\ 1415 Engineering Dr., Madison, WI 53706, USA; loheide@wisc.edu \\ 6 Department of Soil, Water, and Climate, University of Minnesota-Twin Cities, 1991 Upper Buford Circle, \\ St. Paul, MN 55108, USA; cummi428@umn.edu \\ * Correspondence: manocco@ucdavis.edu
}

Received: 6 September 2019; Accepted: 16 October 2019; Published: 22 October 2019

\begin{abstract}
Precision irrigation optimizes the spatiotemporal application of water using evapotranspiration (ET) maps to assess water stress or soil apparent electrical conductivity $\left(\mathrm{EC}_{\mathrm{a}}\right)$ maps as a proxy for plant available water content. However, ET and $\mathrm{EC}_{\mathrm{a}}$ maps are rarely used together. We developed high-resolution ET and $\mathrm{EC}_{\mathrm{a}}$ maps for six irrigated fields in the Midwest United States between 2014-2016. Our research goals were to (1) validate ET maps developed using the High-Resolution Mapping of EvapoTranspiration (HRMET) model and aerial imagery via comparison with ground observations in potato, sweet corn, and pea agroecosystems; (2) characterize relationships between $\mathrm{ET}$ and $\mathrm{EC}_{\mathrm{a}}$; and (3) identify potential precision irrigation benefits across rotations. We demonstrated the synergy of combined $\mathrm{ET}$ and $\mathrm{EC}_{\mathrm{a}}$ mapping for evaluating whether intrafield differences in $\mathrm{EC}_{\mathrm{a}}$ correspond to actual water use for different crop rotations. We found that $\mathrm{ET}$ and $\mathrm{EC}_{\mathrm{a}}$ have stronger relationships in sweet corn and potato rotations than field corn. Thus, sweet corn and potato crops may benefit more from precision irrigation than field corn, even when grown rotationally on the same field. We recommend that future research consider crop rotation, intrafield soil variability, and existing irrigation practices together when determining potential water use, savings, and yield gains from precision irrigation.
\end{abstract}

Keywords: precision agriculture; precision irrigation; evapotranspiration; apparent electrical conductivity; proximal sensing; soil water content; crop rotations; coarse-textured soils; aerial remote sensing

\section{Introduction}

Precision irrigation is an agricultural practice where irrigators optimize the spatiotemporal application of water to maximize yield and minimize environmental impacts, and can reduce water use by up to $50 \%$ compared to traditional irrigation systems [1,2]. Precision irrigators often use proximal 
surveys of soil apparent electrical conductivity $\left(\mathrm{EC}_{\mathrm{a}}\right)$ for decision support when applying water at the subfield scale [3]. Soil $\mathrm{EC}_{\mathrm{a}}$ is influenced by particle size distribution, organic matter content, and structure, which are all also drivers of soil hydraulic properties [4,5]. Ideally, proximal surveys of $\mathrm{EC}_{\mathrm{a}}$ are conducted prior to tilling, planting, and fertilization on recently drained soils near field capacity [6-8]. Under these survey conditions, $\mathrm{EC}_{\mathrm{a}}$ has been demonstrated to predict soil hydraulic properties (e.g., field capacity, plant available water content) and expose water-limited yield gaps on a variety of soil types around the world [4,9-15]. Though $\mathrm{EC}_{\mathrm{a}}$ is an informative proxy for soil hydraulic properties, irrigators still face challenges when making in-season management decisions because maps of $\mathrm{EC}_{\mathrm{a}}$ are only static indicators of plant available water content. To manage water more effectively, irrigators also require information on crop water use dynamics throughout the growing season.

One source of data on crop water use dynamics is in-season maps of evapotranspiration (ET) derived from aerial or satellite imagery. High-resolution maps of ET are useful for identifying portions of a field that are water-stressed. Transpiration is a physiological indicator of crop growth, as it is links the carbon and water cycles [16]. Differences in transpiration drive water availability patterns within a cropping system, generating "hot spots" or areas that are consistently under-or over-irrigated [17]. High-resolution maps of ET can expose irrigation hot spots integrating more biophysical information than crop water stress indicators based on canopy temperature alone [18]. Crops that are consistently under or over irrigated may exhibit low transpiration, which is a physiological indicator of either water or oxygen limitation [19]. However, in order to understand whether crops are consistently under or over irrigated, ET maps need to be compared with maps of plant available water content.

The comparison of high-resolution maps of ET, a dynamic indicator of crop water use, and $\mathrm{EC}_{\mathrm{a}}$, a static indicator of plant available water content, may expose potential benefits and drawbacks to implementing precision irrigation for different crop rotations. Persistent patterns in the magnitude and variability of ET within a cropping system can indicate differences in soil texture and plant available water content $[18,20]$. However, the spatial relationships between ET and plant available water content may change with different crop rotations because of canopy structure, root distribution, physiology, and breeding. As such, we hypothesize that there may be differences in the amount of 'precision' required to optimize water use in irrigated, rotational cropping systems. We test this hypothesis by quantifying the relationships between high resolution estimates of $\mathrm{ET}$ and $\mathrm{EC}_{\mathrm{a}}$ across different crop rotations and fields in a humid agricultural region with coarse soils. A strong relationship between $\mathrm{ET}$ and $\mathrm{EC}_{\mathrm{a}}$ indicates that intrafield differences in crop water use are related to plant available water content, which would be the most pronounced in fields with heterogenous soils. This scenario is a favorable opportunity for precision irrigation intervention-increasing irrigation inputs over the coarsest portions of the field should result in higher transpiration rates. Alternatively, limited relationships between $\mathrm{ET}_{\text {and }} \mathrm{EC}_{\mathrm{a}}$ indicate that soil properties are not driving crop physiology and greater spatial control of irrigation will not impact transpiration. Soil properties will not drive crop physiology through their effects on water availability in (1) fields that have extremely spatially homogenous soils; and/or (2) fields that are being influenced by external management factors such as uneven fertilizer distribution. The greater the variability in intrafield soil texture and hydraulic properties on a uniformly irrigated field, the stronger the relationships should be between ET and $\mathrm{EC}_{\mathrm{a}}$.

We explore $\mathrm{ET}$ and $\mathrm{EC}_{\mathrm{a}}$ relationships across different traditionally irrigated crop rotations to assess potential benefits from precision irrigation interventions on coarse soils. Our research goals were to (1) develop ET maps for irrigated rotational crops using and validating the High-Resolution Mapping of EvapoTranspiration (HRMET) model, aerial imagery, and ground observations; (2) characterize relationships between water use and availability across crop rotations within the same fields and across

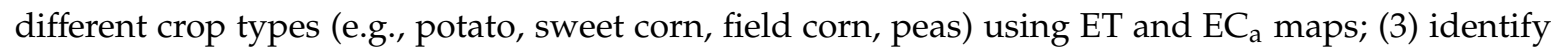
potential precision irrigation benefits on both a field and crop basis. 


\section{Materials and Methods}

\subsection{Site Description}

The northern Great Lakes states of Wisconsin, Michigan, and Minnesota are known for having a humid climate, relatively abundant groundwater supply, and rapidly expanding irrigated agriculture [21]. Coarse-grained glacial aquifers throughout these states support coldwater trout streams, lakes, and wetlands [22]. The Wisconsin Central Sands (WCS, Figure 1) is a relatively small $\left(6400 \mathrm{~km}^{2}\right)$ ecological region in the U.S. northern Great Lakes states where the coarse soils and groundwater irrigation have facilitated intense agricultural productivity that helps make Wisconsin the fourth leading producer of fresh market and processing vegetables in the United States [23]. Groundwater is strongly connected to the $1000 \mathrm{~km}$ of headwater streams, 80 lakes, and abundant wetlands in the WCS, where freshwater conservation, surface water health, and agricultural sustainability are stakeholder priorities [24]. Recent modeling in the WCS has demonstrated that reducing both the frequency and magnitude of groundwater pumping for irrigation could diminish adverse impacts on adjacent surface waters $[25,26]$. Precision irrigation could reduce the frequency and magnitude of groundwater pumping, while maintaining or increasing agricultural productivity in the WCS and similar areas.

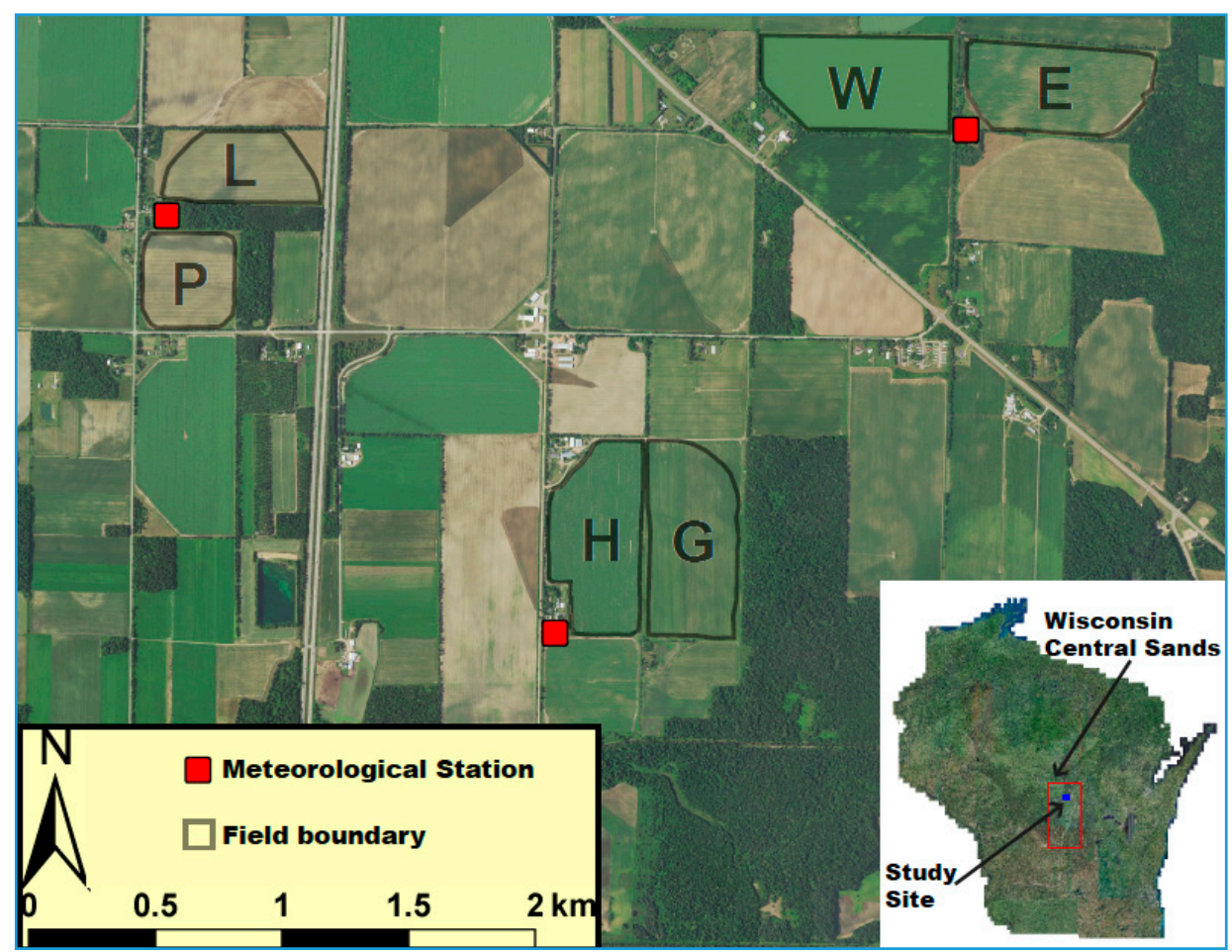

Figure 1. Study site at the Central Sands region in the Wisconsin, U.S.A., as adapted from Nocco et al., 2019. Georeferencing conducted using 2013 National Agriculture Imagery Program data for Portage County, WI.

We used aerial remote sensing to map ET, proximal sensing to map $\mathrm{EC}_{\mathrm{a}}$, and collected complementary ground observations from six commercial fields (denoted H, G, P, L, E, W) in the WCS that had an average planted area of 23 ha for the 2014-2016 growing seasons (Figure 1). We collected aerial imagery and ground observations in partnership with Isherwood Farms, a 600-ha, sixth-generation family farm growing irrigated potatoes, sweet corn, field corn, and peas (Figure 1). Isherwood Farms does not currently use precision irrigation methods (e.g., variable-rate irrigation) and uniformly applies irrigation over each field from a center pivot based on weather monitoring, soil conditions, and crop observations. In these agroecosystems, irrigation typically commences at the end 
of June and supplements rainfall as 6-15 mm events applied every $2-3$ days. All six fields are relatively flat and well drained, with sand, loamy sand, and sandy loam soil textures. Agronomic information for each crop, field, and growing season is presented in Table 1.

Table 1. Cropping systems.

\begin{tabular}{|c|c|c|c|c|}
\hline Site/Year & Planted Area (ha) & Crop & Planting Date & Harvest Date \\
\hline Field H & 26 & & & \\
\hline 2014 & & peas & 22 May & 27 July (pearl millet cover crop) \\
\hline 2015 & & potato & 1 May & 16 September (vine kill 13 August) \\
\hline 2016 & & field corn & 15 May & 11 November \\
\hline Field G & 30 & & & \\
\hline 2014 & & potato & 9 May & 10 September (vine kill 22 August) \\
\hline 2015 & & field corn & 10 May & 28 October \\
\hline 2016 & & sweet corn & 2 June & 31 August \\
\hline Field P & 14 & & & \\
\hline 2014 & & field corn & 12 May & 3 November \\
\hline 2015 & & sweet corn & 30 May & 1 September \\
\hline 2016 & & potato & 6 May & 2 October (vine kill 19 August) \\
\hline Field L & 16 & & & \\
\hline 2014 & & sweet corn & 24 May & 25 August \\
\hline 2015 & & sweet corn & 30 May & 1 September \\
\hline 2016 & & potato & 7 May & 5 October (vine kill 19 August) \\
\hline Field E & 25 & & & \\
\hline 2014 & & sweet corn & 24 May & 25 August \\
\hline 2015 & & potato & 3 May & 21 September (vine kill 20 August) \\
\hline 2016 & & field corn & 16 May & 11 November \\
\hline Field W & 28 & & & \\
\hline 2014 & & field corn & 15 May & 3 November \\
\hline 2015 & & peas & 30 May & 23 July (pearl millet cover crop) \\
\hline 2016 & & potato & 4 May & 28 September (vine kill 19 August) \\
\hline
\end{tabular}

\subsection{Remotely Sensed Maps of ET}

High-resolution maps of ET can be created using satellite or aircraft imagery from multiple wavelength bands to estimate canopy surface temperature and reflectance-based vegetation indices $[17,18,27]$. Canopy surface temperature, aerodynamic temperature, and vegetation indices form the basis for several energy balance models that either explicitly represent vegetation and soil as two sources within a pixel [28-30] or combine vegetation and soil together as a single source within a pixel [31,32]. The majority of these remotely sensed ET models require the designation of 'hot/dry' vs. 'cold/wet' pixels to indicate the minimum and maximum limits of ET within an image and facilitate contextual scaling of ET values between these limits $[28,31,33,34]$. Though this type of contextual scaling approach requires less input data and processing [27] and reduces uncertainty arising from meteorological inputs [33], it has unique drawbacks for precision agricultural applications where fields are relatively homogenous and endmember pixels are challenging to identify [18]. Moreover, in irrigated cropping systems, agricultural fields are maintained to minimize water stress; which makes it especially challenging to identify 'hot/dry' pixels in the relatively small image domain $\left(<1 \mathrm{~km}^{2}\right)$ needed to capture high-resolution data. To meet the unique challenges of mapping ET for irrigated agroecosystems, we used the High-Resolution Mapping of EvapoTranspiration (HRMET) model [18] to estimate ET using airborne imagery and local meteorological forcing. HRMET is a one-dimensional (vertical), process-based energy balance model that uses canopy characteristics, land surface temperature, and meteorological data to estimate latent heat flux as the residual of the energy balance, which can then be converted to ET [18]. HRMET uses a two-source algorithm to estimate 
available energy for vegetation and soil and a single-source iterative calculation of sensible heat flux at a pixel, which eliminates the need for contextual scaling using 'hot/dry' or 'cold/wet' pixels and makes HRMET well suited for precision agricultural applications. For more information about the theory and structure of HRMET, please refer to Zipper and Loheide (2014) [18]. HRMET is an open-source model and the code for R and MATLAB are available at https://github.com/samzipper/HRMET.

Here, we apply HRMET in a gridded manner over our domain using remotely sensed maps of canopy surface temperature (Section 2.3), LAI and $h$ (Section 2.5), and local meteorological data (Section 2.6) as inputs. We ran simulations at a spatial resolution of $2 \mathrm{~m}$ in order to match the resolution of the canopy surface temperature data. The inputs derived from micrometeorological stations required for HRMET include air temperature $\left({ }^{\circ} \mathrm{C}\right)$, wind speed $\left(\mathrm{m} \mathrm{s}^{-1}\right)$, air vapor pressure $(\mathrm{kPa})$, and atmospheric pressure $(\mathrm{kPa})$. Finally, HRMET requires emissivity and albedo values for both vegetation and soil to calculate the energy balance. We used emissivity values of 0.94 and 0.95 for vegetation and soil; assuming a standard deviation of 0.01 because there is a small range in emissivity for these surfaces [16]. We used albedo values of 0.20 and 0.11 for vegetation and irrigated sandy soils maintained near field capacity; assuming a standard deviation of 0.05 [16]. Though HRMET does not require calibration and has already been validated for field corn in Wisconsin via comparison to the Shuttleworth-Wallace approach [18], we provide additional validation from this study in potato, sweet corn, and pea-pearl millet cropping systems.

We assessed the influence of error from all model inputs on ET estimates using a Monte Carlo approach [35]. The mean and standard deviation of all spatial, meteorological, and empirical inputs were used to create an ensemble of input data based on the standard normal distribution. We then solved HRMET 300 times at each pixel with a randomly selected group of inputs for each permutation of HRMET. We conducted a power analysis with field ' $\mathrm{P}$ ' (the smallest field with the shortest model run time) to determine that 300 permutations were required to ensure stability. The 300 ET estimates were used to calculate the final mean and standard deviation of ET for each pixel. Combined, this permutation-based analysis led to 980,534,100 HRMET calculations for our 68 images with 3,268,447 pixels and 300 calculations pixel $^{-1}$. Each HRMET input and its data source are described in Table 2.

Table 2. HRMET inputs.

\begin{tabular}{|c|c|c|c|}
\hline HRMET Input & Spatial Resolution & Source & $\begin{array}{l}\text { Uncertainty Estimation Used to Create } \\
\text { Monte Carlo Ensemble of Input Data }\end{array}$ \\
\hline Canopy temperature & $2 \mathrm{~m}$ & $\begin{array}{l}\text { Thermal imagery } \\
\text { (Section 2.3) }\end{array}$ & $\begin{array}{l}\text { 25-pixel moving window to generate } \\
\text { average canopy temperature per pixel } \\
\text { and standard deviation }\end{array}$ \\
\hline LAI & $5 \mathrm{~m}$ & $\begin{array}{l}\text { Multispectral imagery } \\
\text { (Section 2.3) }\end{array}$ & $\begin{array}{c}\text { Coefficient matrix based on } 50 \\
\text { permutations of LAI-EVI predictive } \\
\text { model (Section } 2.5 \text { ) }\end{array}$ \\
\hline Height & $5 \mathrm{~m}$ & $\begin{array}{l}\text { Multispectral imagery } \\
\text { (Section 2.3) }\end{array}$ & $\begin{array}{c}\text { Coefficient matrix based on } 50 \\
\text { permutations of LAI-EVI predictive } \\
\text { model (Section } 2.5 \text { ) }\end{array}$ \\
\hline Air temperature & fixed & Micromet (Section 2.6) & $\begin{array}{l}\text { 10-min measurements averaged over } \\
\text { flight time from three met stations }\end{array}$ \\
\hline Wind Speed & fixed & Micromet (Section 2.6) & $\begin{array}{l}\text { 10-min measurements averaged over } \\
\text { flight time from three met stations }\end{array}$ \\
\hline Relative humidity & fixed & Micromet (Section 2.6) & $\begin{array}{l}\text { 10-min measurements averaged over } \\
\text { flight time from three met stations }\end{array}$ \\
\hline Solar radiation & fixed & Micromet (Section 2.6) & $\begin{array}{l}\text { 10-min measurements averaged over } \\
\text { flight time from three met stations }\end{array}$ \\
\hline Albedo & fixed & Empirical (Section 2.2) & 0.05 standard deviation imposed \\
\hline Emissivity & fixed & Empirical (Section 2.2) & 0.01 standard deviation imposed \\
\hline
\end{tabular}




\subsection{Airborne Missions and Data Processing}

Twelve airborne missions were conducted during the growing seasons of 2014-2016 (4 per June-August) to capture data during different crop rotations and phenological stages (Table 3). We acquired thermal and multispectral imagery over six fields from equipment mounted on the underside of a single engine three-passenger Cessna aircraft. Though all attempts were made to have airborne missions coincide with cloud-free days, some images were cut off or discarded because of cloud interference. The thermal imagery was captured using a FLIR A320 thermal infrared imaging camera at a pixel size of 1-2 m based on flight elevation (FLIR Systems, Wilsonville, OR, USA). We performed atmospheric corrections using ThermaCAM Researcher Pro 2.7 software (FLIR systems, Wilsonville, OR, USA 2003), georeferenced the data to National Agricultural Imaging Program (NAIP) imagery, and mosaicked images using ArcMap 10 (ESRI, Redlands, CA, USA, 2010). We estimated the mean and standard deviation of surface temperature data using a 25-pixel moving window approach [18].

Table 3. Airborne missions.

\begin{tabular}{|c|c|c|c|c|c|c|}
\hline Mission & Date (DOY) & $\begin{array}{l}\text { Flight } \\
\text { Time } \\
\text { (UTC) }\end{array}$ & $\begin{array}{c}\text { Air } \\
\text { Temperature } \\
\left({ }^{\circ} \mathrm{C}\right)\end{array}$ & $\begin{array}{l}\text { Wind Speed } \\
\qquad\left(\mathrm{m} \mathrm{s}^{-1}\right)\end{array}$ & $\begin{array}{c}\text { Solar } \\
\text { Radiation } \\
\left(\mathrm{W} \mathrm{m}^{-2}\right)\end{array}$ & $\begin{array}{c}\text { Vapor } \\
\text { Pressure } \\
(\mathrm{kPa})\end{array}$ \\
\hline 1 & 6 June 14 (157) & $16: 12-16: 28$ & $24.8(0.5)$ & $1.1(0.7)$ & $690(156)$ & $1.7(0.1)$ \\
\hline 2 & 16 July 14 (197) & $15: 50-16: 17$ & $20.1(0.5)$ & $1.3(0.5)$ & 791 (157) & $1.3(0.1)$ \\
\hline 3 & 23 July 14 (204) & 15:07-15:24 & $21.6(0.3)$ & $1.2(0.3)$ & $650(55)$ & $1.7(0.0)$ \\
\hline 4 & 7 August 14 (219) & $15: 38-15: 54$ & $24.1(0.2)$ & $1.3(0.7)$ & $664(18)$ & $1.8(0.1)$ \\
\hline 5 & 16 June 15 (167) & $17: 15-17: 45$ & $21.4(0.8)$ & $0.8(0.3)$ & $1058(83)$ & $1.4(0.0)$ \\
\hline 6 & 02 July 15 (183) & $16: 21-16: 36$ & $20.3(0.3)$ & $0.8(0.4)$ & $785(3)$ & $1.3(0.0)$ \\
\hline 7 & 27 July 15 (208) & $16: 02-16: 19$ & $27.6(0.5)$ & $1.1(0.4)$ & $730(84)$ & $2.4(0.0)$ \\
\hline 8 & 11 August 15 (223) & $15: 37-15: 58$ & $23.5(0.4)$ & $1.2(0.1)$ & $500(227)$ & $1.8(0.0)$ \\
\hline 9 & 17 June 16 (169) & $15: 40-16: 13$ & $25.6(0.1)$ & $0.9(0.6)$ & $727(5)$ & $1.9(0.1)$ \\
\hline 10 & 1 July 16 (183) & $15: 42-16: 19$ & $18.3(0.2)$ & $2.1(0.4)$ & $813(10)$ & $1.4(0.1)$ \\
\hline 11 & 1 August 16 (214) & $15: 34-16: 05$ & $25.7(0.2)$ & $0.7(0.3)$ & $691(1)$ & $2.2(0.1)$ \\
\hline 12 & 18 August $16(231)$ & $16: 15-16: 38$ & $27.4(0.4)$ & $1.6(1.0)$ & $543(117)$ & $2.4(0.1)$ \\
\hline
\end{tabular}

We collected multispectral images using a six-sensor Tetracam Multi Camera Array (MCA) system (Tetracam Inc., Los Angeles, CA, USA) at a pixel size of 0.6-0.8 m with multiband sensors centered at 450, 570, 620, 650, 670, and $860 \mathrm{~nm}$. Multispectral images were coregistered using Pixelwrench (Tetracam Inc., Los Angeles, CA, USA 2001) and georeferenced to NAIP imagery. We converted digital numbers captured by the MCA system to surface reflectance values using the control points method described by Kang et al., (2016) [36]. In brief, we chose 3-5 stable control points (e.g., healthy green grass, concrete parking area) present in each image and collected ten spectral reflectance measurements at $1 \mathrm{~nm}$ resolution from each point using an ASD handheld spectroradiometer at the end of the 2016 field season (Analytical Spectral Devices, Inc., Boulder, CO, USA). We averaged spectral reflectance measurements at $10 \mathrm{~nm}$ intervals matching each MCA band in order to build linear relationships between digital numbers and surface reflectance values at each control point, which we used to convert digital numbers to surface reflectance values. All digital number-surface reflectance fits had $R^{2}$ values $>0.71$. We spatially aggregated images to $5 \mathrm{~m}$ resolution to represent the canopy scale of indices with both plants and soil in each pixel [27]. We computed the Enhanced Vegetation Index (EVI) $[37,38]$ from aggregated images using surface reflectance data. Overpass time, image collection height, and meteorological conditions for each mission are detailed in Table 2.

\section{4. $E C_{a}$ Surveys}

We partnered with a precision agricultural consulting firm to conduct proximal surveys of $\mathrm{EC}_{\mathrm{a}}$ prior to cultivation when soil moisture was at or near field capacity on 13 April 2015 for fields P, L, E, and W and 21 April 2016 for fields H and G (Precision Waterworks LLC, Plainfield, WI, USA). 
Measurements were collected using the Veris Soil EC 3100 (Veris Technologies, Salina, KS, USA), which is an instrument that estimates bulk shallow ( $\mathrm{EC}_{\mathrm{a}_{\mathrm{a} s h}}$, integrated over $0-0.3 \mathrm{~m}$ soil depth) and deep ( $\mathrm{EC}_{\mathrm{a}_{-} \mathrm{dp}}$, integrated over 0-0.9 $\mathrm{m}$ ) $\mathrm{EC}_{\mathrm{a}}$ via electromagnetic induction [39]. We collected $\mathrm{EC}_{\mathrm{a}}$ point data from 18-m wide transects and made a measurement every 2-3 $\mathrm{m}$ along each transect. All $\mathrm{EC}_{\mathrm{a}}$ survey data were temperature corrected to $25^{\circ} \mathrm{C}$ using the model of Sheets and Hendrickx (1995) corrected by Corwin and Lesch (2005) $[40,41]$. We interpolated $\mathrm{EC}_{\mathrm{a}}$ survey data $\left(n=215-230 \mathrm{ha}^{-1}\right)$ to a 2-m grid for all six fields $\left(n=2100-2200 \mathrm{ha}^{-1}\right)$ using ordinary kriging and spherical variogram models [42,43] in ArcMap 10 (ESRI, Redlands, CA, USA, 2010; Figure 2). A companion study established that these $\mathrm{EC}_{\mathrm{a} \_ \text {sh }}$ and $\mathrm{EC}_{\mathrm{a} \_\mathrm{dp}}$ maps predict particle size, soil organic matter, and field capacity from the six fields on Isherwood Farms in this study [9]. Thus, we use the same $\mathrm{EC}_{\mathrm{a}}$ maps as proxies for plant available water content. High $\mathrm{EC}_{\mathrm{a}}$ values within a field signify relatively higher plant available water, higher field capacity, greater silt and clay content, and higher soil organic matter, while low $\mathrm{EC}_{\mathrm{a}}$ values within a field signify relatively lower plant available water and greater sand content. Direct $\mathrm{EC}_{\mathrm{a}}$ comparisons are relative to each field in this study and a particular $\mathrm{EC}_{\mathrm{a}}$ value on one field does not necessarily indicate the same plant available water content at the same $\mathrm{EC}_{\mathrm{a}}$ value on another field.

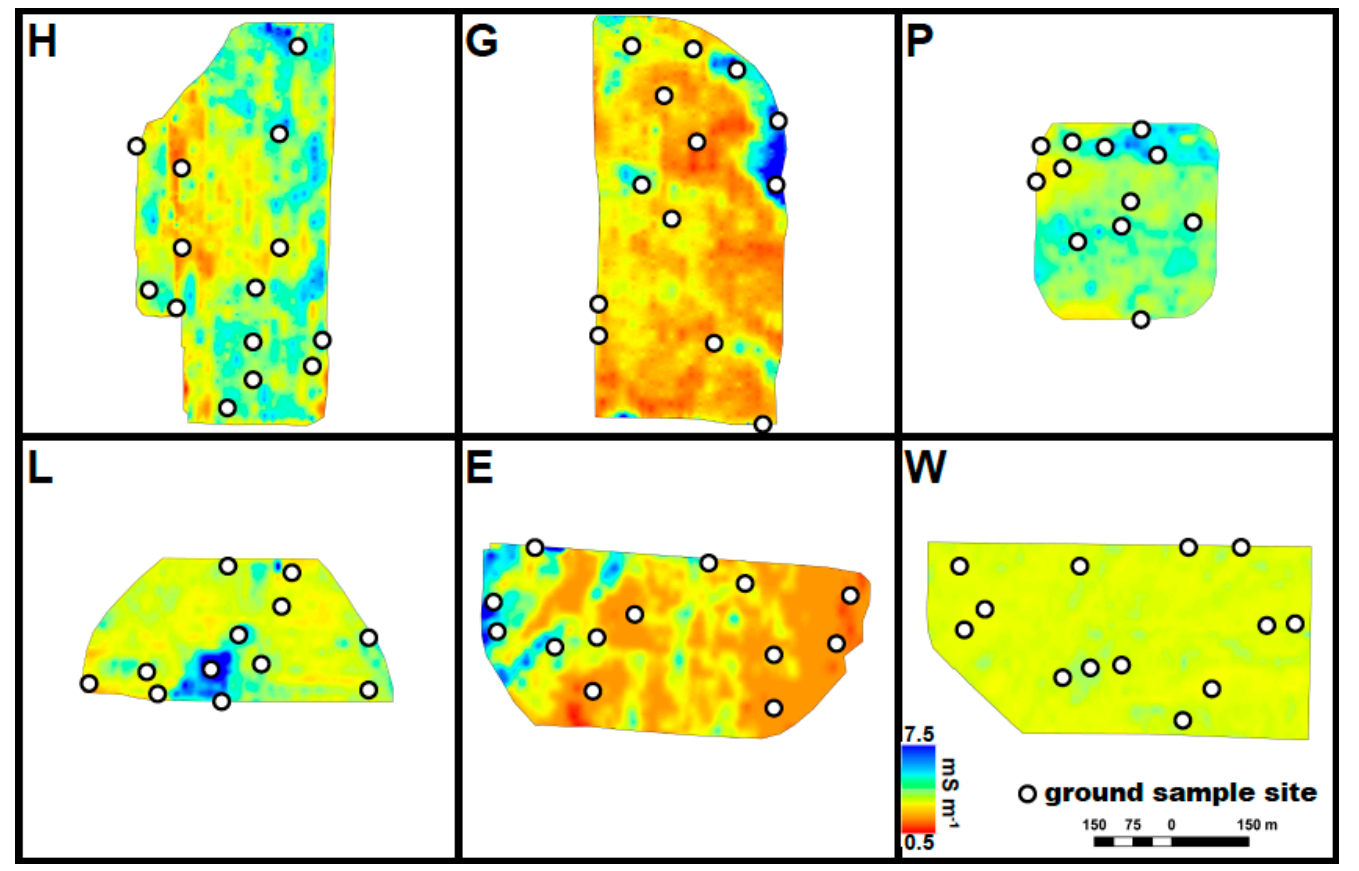

Figure 2. Maps of apparent soil electrical conductivity $\left(\mathrm{EC}_{\mathrm{a}}\right)$, as adapted from Nocco et al., 2019. Field labels refer to Figure 1; EC a surveys were conducted on in 13 April 2015 for fields P, L, E, W and on 21 April 2016 for fields H and G.

\subsection{Crop Phenology}

We collected weekly measurements of leaf area index $\left(\mathrm{LAI}, \mathrm{m}^{2} \mathrm{~m}^{-2}\right)$ during the growing seasons of 2015-2016 using a LI-COR LAI-2200 plant canopy analyzer (LI-COR Inc., Lincoln, NE, USA). LAI measurements were collected under diffuse light conditions (e.g., sunrise or sunset) or clear skies. Scattering effects were removed for clear sky measurements using a bidirectional model [44] embedded in post-processing software (FV2200 2.0, LI-COR Inc., Lincoln, NE, USA). Weekly LAI measurements were collected within a 5-m radius of locations demarcated in Figure 2. Weekly measurements of canopy height $(h)$ were collected within 3-4 days of each airborne mission at locations demarcated in Figure 2. We used smoothing splines in the MATLAB Curve Fitting Toolbox (MATLAB, 2015b) to interpolate LAI and $h$ values to the date of each airborne mission.

Vegetation indices such as EVI have often been used to predict LAI and $h$ for energy balance modeling using empirical relationships developed from ground-based measurements of phenology $[45,46]$. 
The relationships between EVI, LAI, and $h$ in cropping systems are best represented by different simple functional forms including linear, power, and exponential fits with two or three coefficients [36]. We compiled all 2015-2016 spatially explicit LAI, $h$, and EVI values to generate models to predict LAI and $h$ from EVI for field corn, sweet corn, potato, peas, and pearl millet (mid-season cover crop following peas). The data were fit using a nonlinear least squares regression approach with six possible functional forms (linear, power, and exponential with two or three coefficients). We chose the best functional form for each crop model of LAI or $h$ based on minimizing RMSE values. We used a permutation-based approach [18] to estimate uncertainty in crop models of LAI and $h$ for each remotely sensed image. We executed 50 permutations of LAI or $h$ models for each crop data set, each time eliminating 5 random data points, fitting the remaining data, and using the eliminated points to determine the model fit; thereby generating 50 fitted LAI and $h$ models for each crop. We then used the 50 different sets of model coefficients to fit LAI and $h$ at each EVI pixel, generating mean and standard deviations of LAI and $h$ for each image. Functional forms, coefficients, and goodness of fit statistics for each chosen LAI or $h$ model are tabulated in Appendix A. LAI maps are presented for each mission in Figure 3.

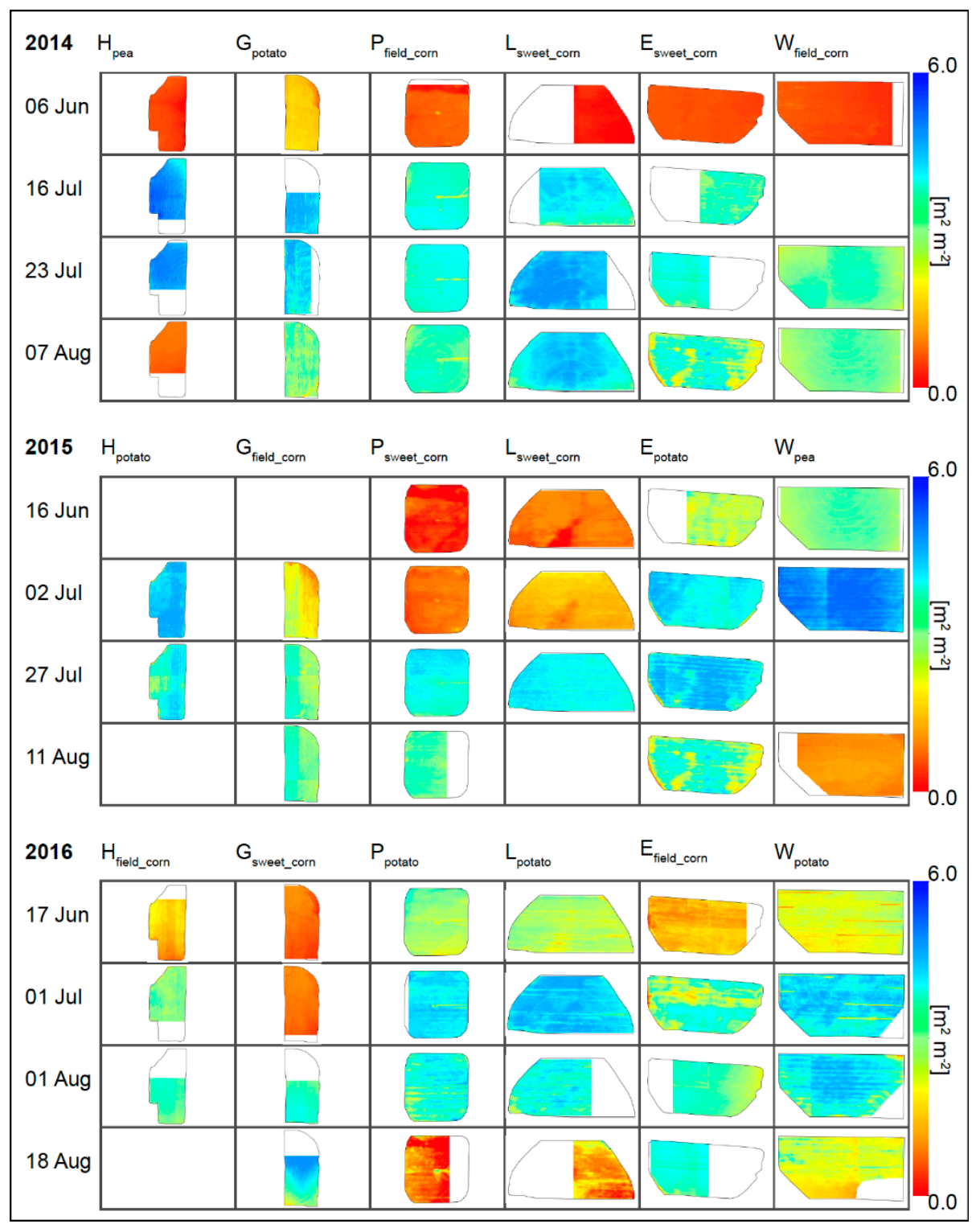

Figure 3. Leaf area index $\left(\mathrm{m}^{2} \mathrm{~m}^{-2}\right)$ for fields $\mathrm{H}, \mathrm{G}, \mathrm{P}, \mathrm{L}, \mathrm{E}$, and $\mathrm{W}$ for twelve airborne missions in 2014-2016. All maps are linearly scaled to the same color bar. Blank spaces indicate missing imagery because of cloud interference during missions. 


\subsection{Micrometeorology}

Three micrometeorological weather stations were installed (Figure 1, ' $\mathrm{M}^{\prime}$ ) adjacent to fields in 2013 according to the World Meteorological Organization guide for agrometeorological observations from fixed stations [47]. Instruments measuring precipitation (S-RGA-M0002; Onset Computer Corp., Bourne, MA, USA), temperature and relative humidity (S-THB-M002; Onset Computer Corp., Bourne, MA, USA), wind speed (S-WSB-M003; Onset Computer Corp., Bourne, MA, USA), and solar radiation (silicon pyranometer, S-LIB-M003; Onset Computer Corp., Bourne, MA, USA) were mounted on 2-m tripods over grass surfaces (M-TPB-KIT; Onset Computer Corp., Bourne, MA, USA). Measurements were collected every $10 \mathrm{~min}$ and recorded using a HOBO (Onset Computer Corp., Bourne, MA, USA) micro station data logger. We estimated cumulative reference ET (RET) as an index of evaporative demand for each growing season using micrometeorological data and American Society of Civil Engineers (ASCE) standardized equations for a uniform grass crop [48,49]. Isherwood Farms provided irrigation records, which were validated using soil moisture measurements and three additional rain gauges [50]. Two meteorological stations malfunctioned during the 2015 field season, so all 2015 values are derived from the station between fields ' $\mathrm{L}$ ' and ' $\mathrm{P}$ '. Cumulative precipitation, irrigation, and reference evapotranspiration for the 2014-2016 growing seasons are presented in Figure 4.
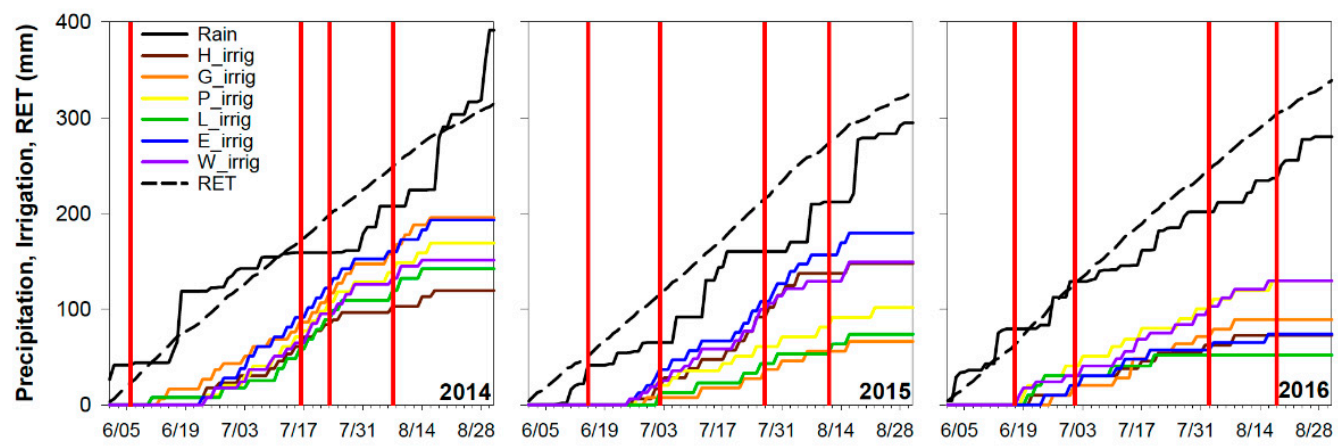

Figure 4. Cumulative precipitation $(\mathrm{mm})$, irrigation $(\mathrm{mm})$, and reference evapotranspiration ( $\mathrm{mm}$, 'RET') data for 1 June-31 August for 2014-2016 growing seasons on Isherwood Farms. Irrigation time series for fields H, G, P, L, E, W are labelled as H_irrig, G_irrig, P_irrig, L_irrig, E_irrig, and W_irrig, respectively. Airborne missions are demarcated by red vertical lines.

For airborne missions where the field or sweet corn canopy height exceeded $2 \mathrm{~m}$, we used meteorological data from a $7.6 \mathrm{~m}$ high National Weather Service (NWS) cooperative observer station $4 \mathrm{~km}$ from the field site to run HRMET over the fields with crops $>2 \mathrm{~m}$. Wind speed measurements must be taken above canopy height when using HRMET, as sensible heat flux is calculated based on the gradient between surface canopy temperature and the air temperature above the canopy. The heights of wind speed measurements are standardized and adjusted using logarithmic profiles in the calculation of the friction velocity and aerodynamic resistance. We estimated uncertainty in meteorological inputs using data collected from all stations $30 \mathrm{~min}$ before and after the mean image collection time (6-7 data points/station) for each airborne mission. Because air temperature and solar radiation are time-dependent inputs, we estimated uncertainty using the standard deviation of the residuals from a linear regression of the one-hour time series.

\subsection{Shuttleworth-Wallace Validation}

We validated HRMET estimates of instantaneous ET $\left(\mathrm{mm} \mathrm{hr}^{-1}\right)$ for potato, sweet corn, and pea-pearl millet cropping systems via comparison to the Shuttleworth-Wallace model, which uses a dual-source approach that is ideal for both sparse and full canopy conditions and allowed us to generate hourly, point-based ET estimates appropriate for validating HRMET [51]. In addition to the phenological and meteorological inputs also required for HRMET, the Shuttleworth-Wallace model requires surface soil moisture and stomatal conductance inputs to estimate surface resistance. 
We collected surface soil moisture and stomatal conductance measurements during or immediately after airborne missions in 2015-2016. Within an hour of each airborne mission, we collected 7-10 measurements of stomatal conductance (SC-1 Leaf Porometer, Decagon Devices, Inc., Pullman, WA, USA) and 20 measurements of surface soil moisture (Thetaprobe ML2x, Delta-T Devices, Cambridge, UK) at 2-5 locations in potato, sweet corn, or pea-pearl millet agroecosystems. Stomatal conductance and surface soil moisture measurement locations were always chosen to coincide with LAI and $h$ data collection locations demarcated in Figure 2. These measurements provided us with $2-5$ validation points for each of the 8 airborne missions in 2015-2016. The number of validation points depended on the speed with which we could calibrate the porometer and move among calibration sites within an hour of the flight. Any Shuttleworth-Wallace points that did not have a complementary HRMET estimate (due to clouds) were eliminated from the validation, leaving 26 total validation points. The surface soil moisture measurements were used to calculate surface soil resistance using the method of Camillo and Gurney (1986) [52] and assuming a uniform saturated soil water content of $0.41 \mathrm{~m}^{3} \mathrm{~m}^{-3}$ for loamy sand [53]. We used a sunlight extinction model [16] to estimate total sunlit LAI and a big leaf approach to upscale stomatal conductance measurements to total bulk canopy resistance [51].

\subsection{Relative Indices and Ordinal Correlation Analyses}

We used the relative ET index $\left(\mathrm{ET}_{\mathrm{R}}\right)$ [18] to examine intrafield variability in ET over different crop rotations. To calculate $\mathrm{ET}_{\mathrm{R}}$, we linearly normalized mean $\mathrm{ET}$ rates to the 5th and 95th percentile for each mosaicked set of images for a single field on a given measurement date. Thus, an $\mathrm{ET}_{\mathrm{R}}$ value of 1 indicates the maximum ET rates within a field, while an $\mathrm{ET}_{\mathrm{R}}$ value of 0 indicates minimum $\mathrm{ET}$ rates within a field. To examine relationships between $\mathrm{ET}_{\mathrm{R}}$ and plant available water content across fields and rotations, we also linearly normalized shallow and deep $\mathrm{EC}_{\mathrm{a}}$ values for each field to the 5th and 95th percentile.

Though ET is a temporally variable process subject to external forcing (e.g., seasonality, weather), we are interested in understanding how its intrafield spatial variability and sensitivity to differences in soil properties responds to changes across different crop rotations. Thus, we used the normalized $\mathrm{ET}_{\mathrm{R}}$ index to examine the strength and direction of relationships with normalized $\mathrm{EC}_{\mathrm{a}_{\_} \mathrm{sh}}$ and $\mathrm{EC}_{\mathrm{a}_{\_} \mathrm{dp}}$ values within each field using ordinal correlation analyses on a per-pixel basis $(n=30,830-63,031$ pixels per field). We built correlation coefficient matrices using Kendall's tau coefficients. The Kendall's tau coefficient is a nonparametric measure of correlation for ordinal, continuous data assuming a monotonic relationship [54]. Tau values range from -1 to 1 , where -1 is a perfect negative relationship, 0 indicates no relationship, and 1 is a perfect positive relationship. Statistical significance was assessed at an alpha level of 0.001 for all correlations in this study. We assumed that the relationship between ET and $\mathrm{EC}_{\mathrm{a}}$ is monotonic in coarse soils, where ET limitation due to anoxic conditions is rare. Kendall's tau correlation matrices have 4-5 variables per field including $\mathrm{EC}_{\mathrm{a} \_ \text {sh }}, \mathrm{EC}_{\mathrm{a} \_\mathrm{dp}}$, and average $\mathrm{ET}_{\mathrm{R}}$ for each crop grown between 2014-2016. We also examined the strength and direction of relationships between $\mathrm{EC}_{\mathrm{a} \_ \text {sh }}, \mathrm{EC}_{\mathrm{a} \_\mathrm{dp}}$, and $\mathrm{ET}_{\mathrm{R}}$ for potato, sweet corn, and field corn across all six fields using Kendall's tau correlation coefficient matrices. There were not enough pea-pearl millet rotations to include in the analyses across all fields.

We also used ordinal correlation analyses to identify the relationships between $\mathrm{EC}_{\mathrm{a}}$ and $\mathrm{ET}$ across different crops and fields. Strong, significant correlations between $\mathrm{ET}_{\mathrm{R}}$ and $\mathrm{EC}_{\mathrm{a}}$ indicate greater potential precision irrigation benefits because relatively coarser portions of the field have lower ET rates due to water limitations not observed on relatively finer portions of the field. Precision irrigation would reduce the correlation between $\mathrm{ET}_{\mathrm{R}}$ and $\mathrm{EC}_{\mathrm{a}}$ by increasing water applied to coarser portions of the field. Thus, weak or nonexistent relationships between $\mathrm{ET}_{\mathrm{R}}$ and $\mathrm{EC}_{\mathrm{a}}$ indicate that either specific crop rotations or fields would not benefit from increased spatial control of irrigation applications. 


\section{Results}

\subsection{Validation of HRMET in Irrigated Potatoes, Sweet Corn, Peas, and Pearl Millet}

Using aerial imagery, onsite meteorological data, and ground observations to drive HRMET was an effective approach for developing high-resolution maps of ET. HRMET performed comparably to the Shuttleworth-Wallace ET model (Figure 5). The slope of the linear relationship between the Shuttleworth-Wallace and HRMET models was 1.032, the RMSE was $0.074 \mathrm{~mm} \mathrm{hr}^{-1}$, and the $\mathrm{R}^{2}$ value was 0.814 across all points $(n=26)$. Comparing across only potato validation points $(n=10)$, the slope of the linear relationship between the Shuttleworth-Wallace and HRMET models was 1.087, the RMSE was $0.038 \mathrm{~mm} \mathrm{hr}^{-1}$, and the $\mathrm{R}^{2}$ value was 0.943 . Comparing across only sweet corn validation points $(n=11)$, the slope of the linear relationship between the Shuttleworth-Wallace and HRMET models was 1.079 , the RMSE was $0.102 \mathrm{~mm} \mathrm{hr}^{-1}$, and the $\mathrm{R}^{2}$ value was 0.700 . There are not enough validation points to separately compare pea $(n=3)$ and pearl millet $(n=2)$ crop validations.

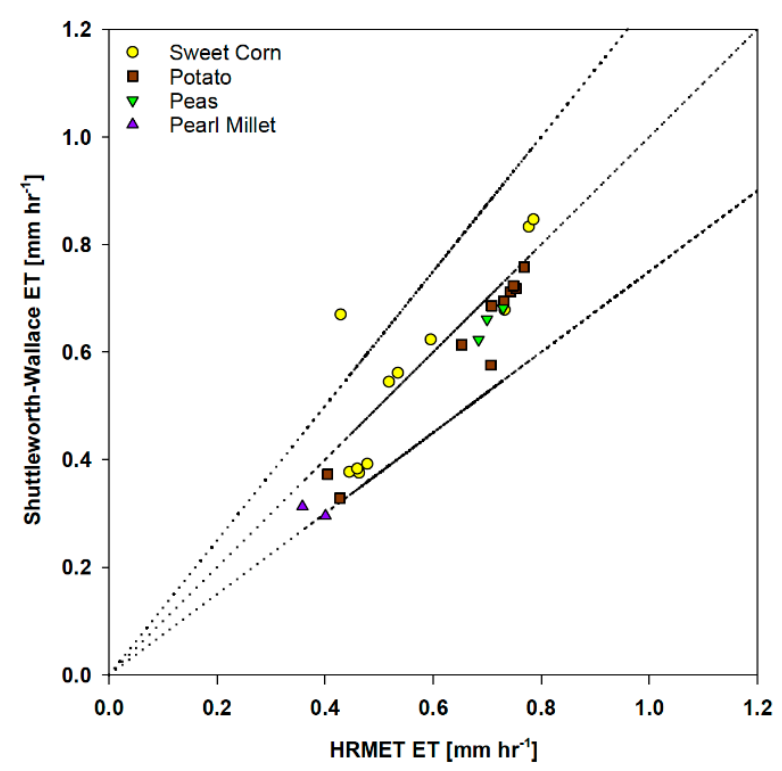

Figure 5. Comparison of HRMET and Shuttleworth-Wallace ET rates $\left(\mathrm{mm} \mathrm{hr}^{-1}\right)$ for irrigated sweet corn, potatoes, peas, and pearl millet cropping systems. The dashed lines represent a $1: 1$ fit $\pm 25 \%$ error.

HRMET performed well in both sparse and full canopy conditions. The validation included sparse canopy conditions during the June flights for sweet corn, potato, and peas as well as the August 2015 flight for pearl millet. Full canopy conditions were validated via the July flights for sweet corn, potato, and peas. Sparse canopy conditions during senescence were also validated for potato during the August 2015 and 2016 flights. In this study, HRMET estimates of ET were $0.1 \mathrm{~mm} \mathrm{hr}^{-1}$ closer to Shuttleworth-Wallace estimates than they were in a rainfed field corn study in southern Wisconsin during a droughty year [18]. We suggest that the improved agreement between HRMET and Shuttleworth-Wallace in the WCS is attributed to the removal of water limitations as the Shuttleworth-Wallace model is intended to estimate ET from well-watered canopies [51,55].

\subsection{Uncertainty in Remotely-Sensed ET Estimates}

We observed little to no spatial variability in the standard deviation of ET per pixel, indicating that the uncertainty of ET estimates is derived from the variability of meteorological data (Figures 6 and 7). The uncertainty in per pixel ET estimates of 8 out of 12 missions was low and CVs averaged across all pixels and fields were 6-15\%. The four airborne missions occurring on 11 August 2015, 6 June 2014, 18 August 2016, and 16 July 2014 had higher uncertainty in per pixel ET estimates with coefficients of variation (CVs) of $48,46,30$, and $24 \%$ averaged across all pixels for all fields. These four dates also had 
the highest standard deviations in solar radiation (117-227 $\mathrm{W} \mathrm{m}^{-2}$ ) observed across all 12 airborne missions (Table 2). Observationally, these were four missions where cloud conditions were rapidly changing and it was challenging to capture thermal and multiband imagery around intermittent cloud cover.

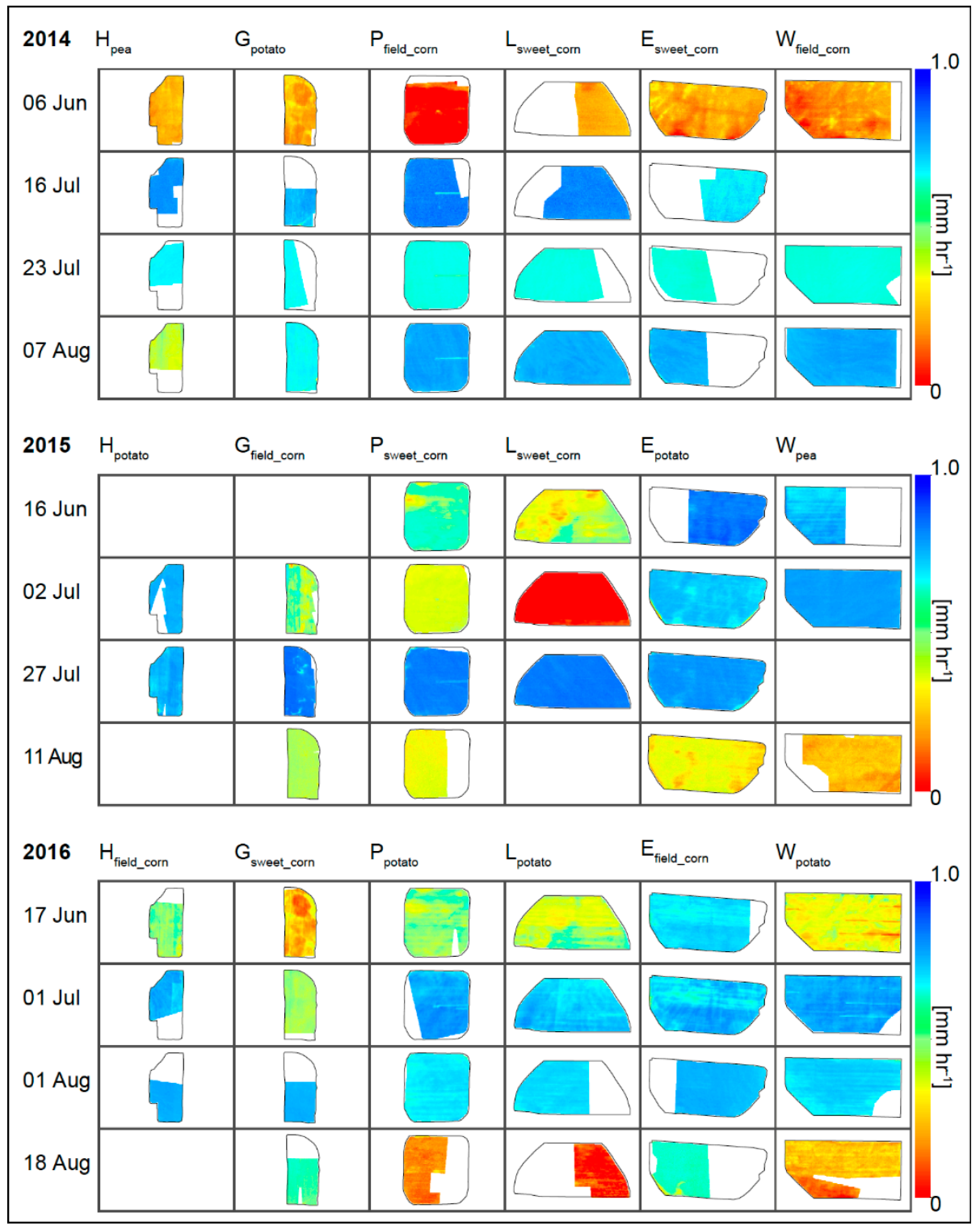

Figure 6. HRMET-calculated mean ET rates $\left(\mathrm{mm} \mathrm{hr}^{-1}\right)$ for fields $\mathrm{H}, \mathrm{G}, \mathrm{P}, \mathrm{L}, \mathrm{E}$, and $\mathrm{W}$ for 12 airborne missions in 2014-2016. All maps are linearly scaled to the same color bar. Blank spaces indicate missing imagery because of cloud interference during missions. 


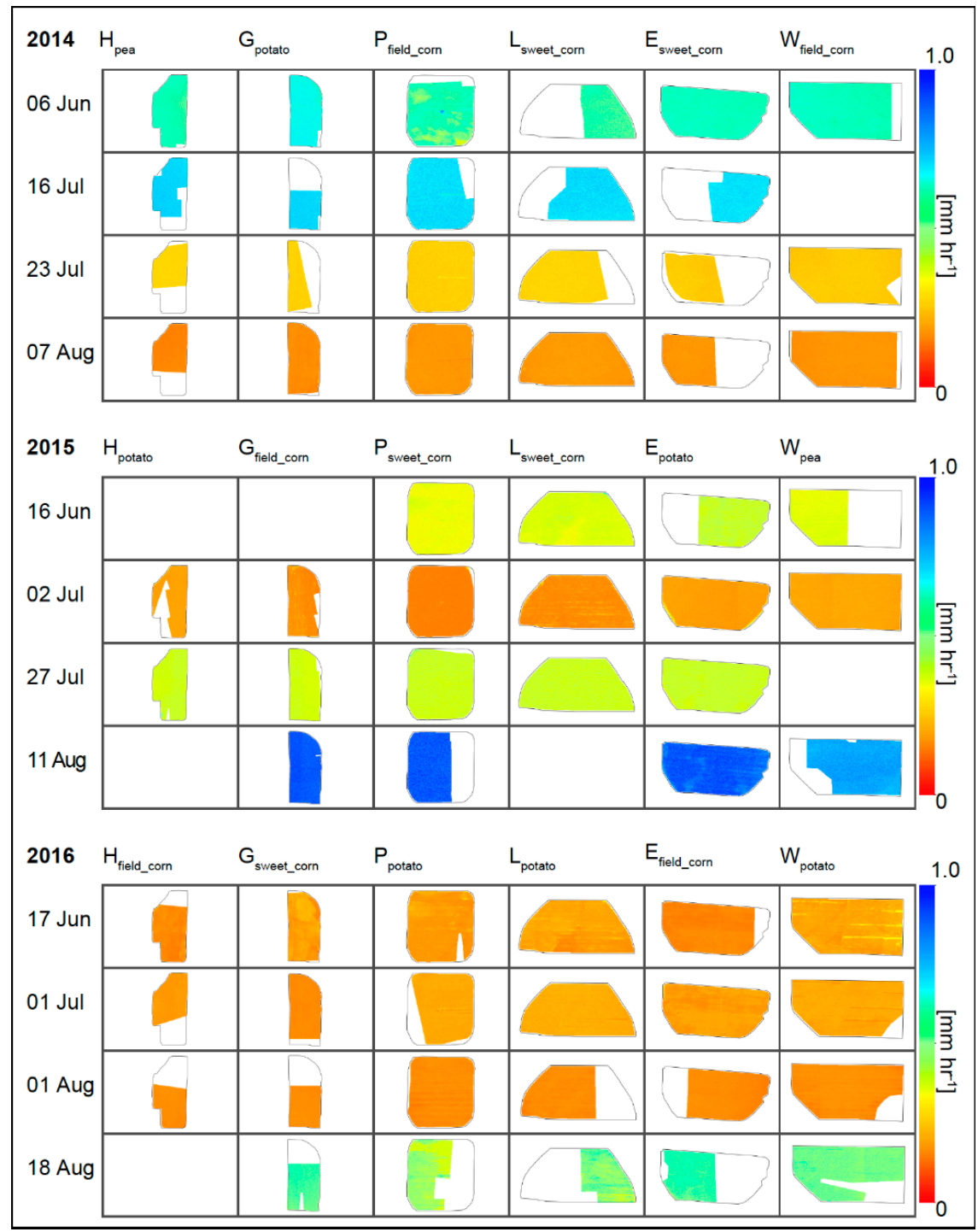

Figure 7. Standard deviation of HRMET-calculated ET rates $\left(\mathrm{mm} \mathrm{hr}^{-1}\right)$ for fields $\mathrm{H}, \mathrm{G}, \mathrm{P}, \mathrm{L}, \mathrm{E}$, and W for 12 airborne missions in 2014-2016. All maps are linearly scaled to the same color bar. Blank spaces indicate missing imagery because of cloud interference during missions.

\subsection{Relationships between Water Use and Availability}

Relative ET $\left(\mathrm{ET}_{\mathrm{R}}\right)$ maps facilitate the comparison of intrafield variability in ET across airborne missions (Figure 8). Qualitatively, several of the $\mathrm{ET}_{\mathrm{R}}$ maps exhibit similar patterns to $\mathrm{EC}_{\mathrm{a}}$ maps (Figure 2), especially for airborne missions with limited canopy cover where soil evaporation dominates ET. There were significant correlations $(p<0.001)$ between $\mathrm{ET}_{\mathrm{R}}$ and $\mathrm{EC}_{\mathrm{a}}$ on each field with Kendall's tau values ranging from $0.05-0.47$ across all rotations (Figure 9) and across all six fields with a tau values of $0.27-0.33,0.3-0.31$, and $0.11-0.14$ for potato, sweet corn, and field corn, respectively (Figure 10). We found that $\mathrm{ET}_{\mathrm{R}}$ had relatively similar correlation coefficients with both $\mathrm{EC}_{\mathrm{a}_{-} \text {sh }}$ and $\mathrm{EC}_{\mathrm{a}_{-} \mathrm{dp}}$ across each rotation. Correlations between $\mathrm{ET}_{\mathrm{R}}$ and $\mathrm{EC}_{\mathrm{a}}$ were the strongest on fields $\mathrm{E}$ and $\mathrm{G}$ and the weakest on field $\mathrm{H}$. These significant relationships between $\mathrm{ET}_{\mathrm{R}}$ and $\mathrm{EC}_{\mathrm{a}}$ indicate that subfield differences in plant available water content drive crop water use at the subfield scale. This means that precision irrigation interventions (e.g., variable rate irrigation using management zones) should provoke more efficient crop water use. Some potential precision water management recommendations based on strongly correlated measurements of $\mathrm{ET}_{\mathrm{R}}$ and $\mathrm{EC}_{\mathrm{a}}$ are highlighted in Table 4. 


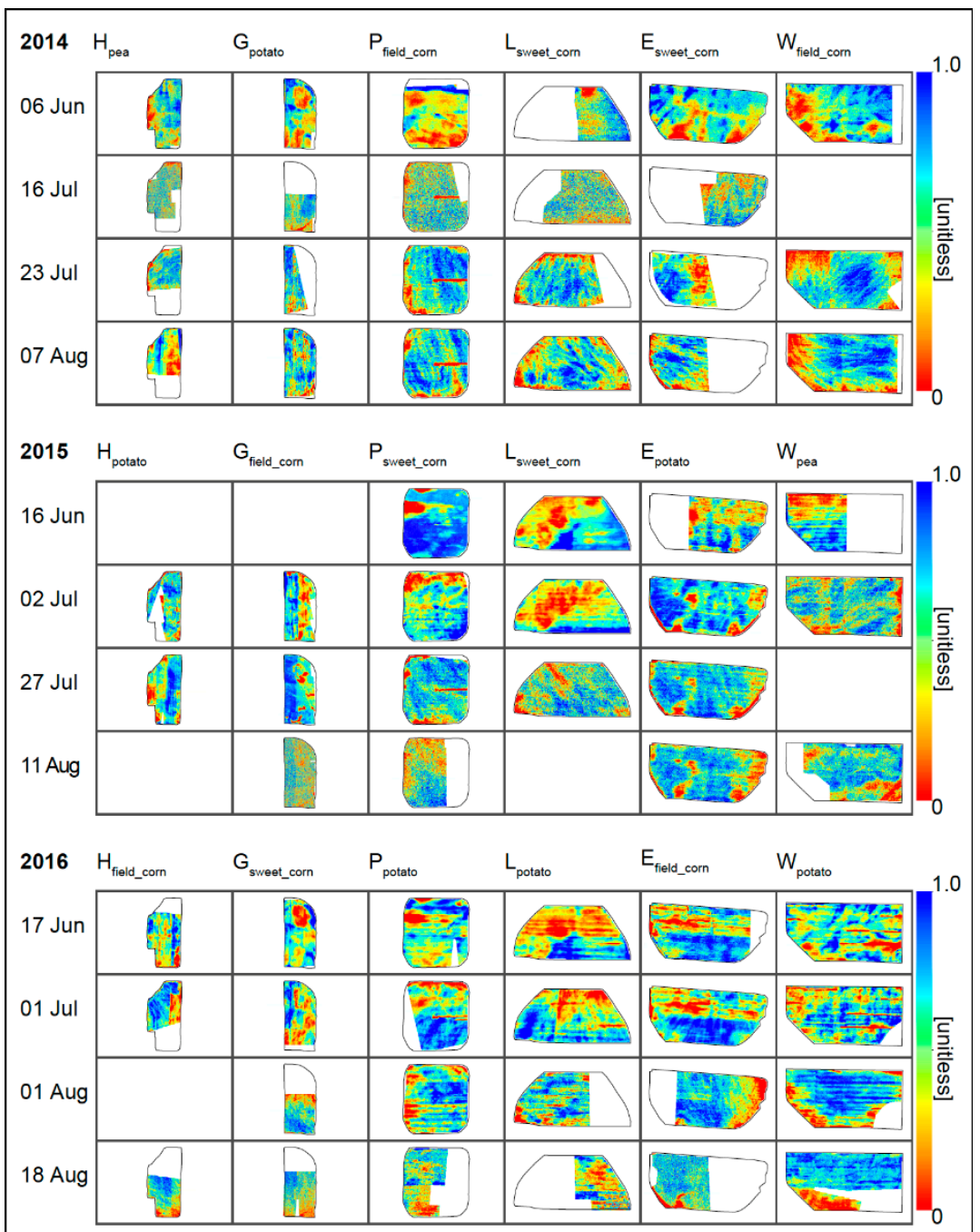

Figure 8. Maps of relative evapotranspiration ( $\mathrm{ET}_{\mathrm{R}}$, unitless) for fields $H, G, P, L, E$, and $W$ for 12 airborne missions in 2014-2016. Color bars represent linearly normalized mean $\mathrm{ET}_{\mathrm{R}}$ rates to the 5th (red) and 95th (blue) percentile for each field. Blank spaces indicate missing imagery because of cloud interference during missions.
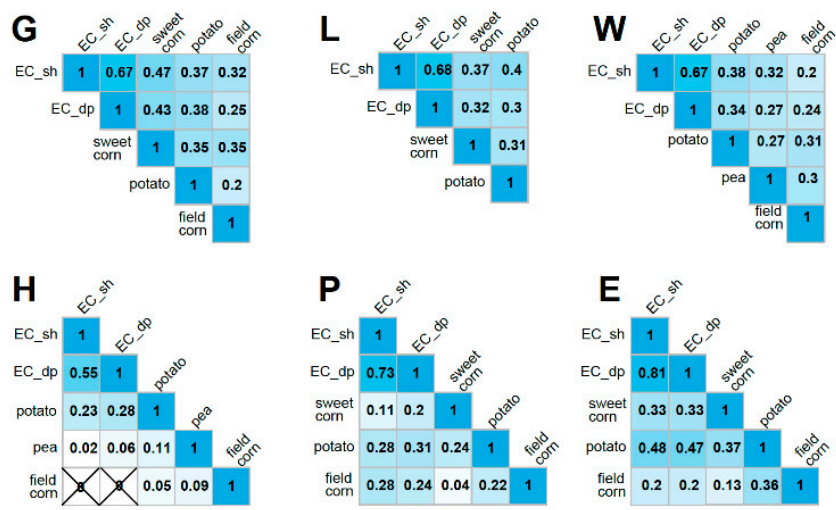

Figure 9. Kendall's tau correlation coefficient matrices for fields H, G, P, L, E, and W Correlations are for the following parameters: shallow and deep apparent electrical conductivity (EC_sh and EC_dp, respectively) and relative evapotranspiration for each crop rotation ('sweet corn', 'potato', 'pea', and 'field corn'). Correlations are all statistically significant at an alpha level of 0.001 unless they are crossed out with ' $X$ ' symbols. 


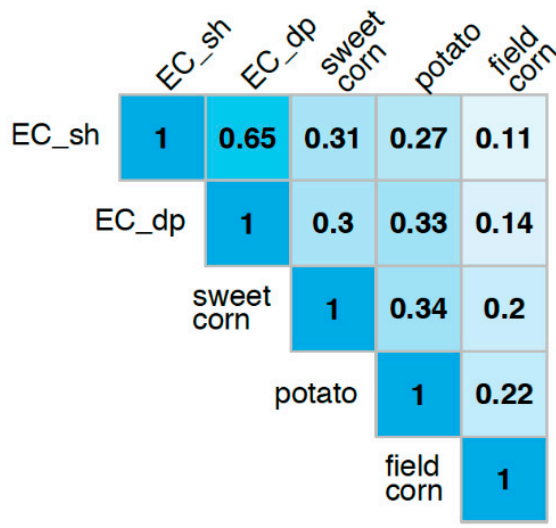

Figure 10. Kendall's tau correlation coefficient matrices for all six fields (H, G, P, L, E, and W) together. Correlations are for the following parameters: shallow and deep apparent electrical conductivity (EC_sh and EC_dp, respectively) and relative evapotranspiration for each crop rotation ('sweet corn', 'potato', and 'field corn'). Correlations are all statistically significant at an alpha level of 0.001 .

Table 4. Recommended precision irrigation actions based on intrafield relative ET and $\mathrm{EC}_{\mathrm{a}}$.

\begin{tabular}{cccc}
\hline $\begin{array}{c}\text { Intrafield Relative } \\
\text { ET }\end{array}$ & $\begin{array}{c}\text { Intrafield Relative } \\
\mathbf{E C}_{\mathbf{a}}\end{array}$ & Crop Soil Water Status & $\begin{array}{c}\text { Recommended } \\
\text { Precision Irrigation } \\
\text { Actions }\end{array}$ \\
\hline Low & Low & $\begin{array}{c}\text { Soils have relatively lower plant } \\
\text { available water, crops are under } \\
\text { water-stress }\end{array}$ & $\begin{array}{c}\text { Increase irrigation, } \\
\text { reduce drainage }\end{array}$ \\
\hline Low & High & $\begin{array}{c}\text { Soils have relatively higher plant } \\
\text { available water, crops are under } \\
\text { oxygen-stress } 1\end{array}$ & $\begin{array}{c}\text { Reduce irrigation, } \\
\text { increase drainage }\end{array}$ \\
\hline Moderate to High & Low & $\begin{array}{c}\text { Soils have relatively lower plant } \\
\text { available water, but crops are } \\
\text { well-watered }\end{array}$ & No change \\
\hline Moderate to High & High & $\begin{array}{c}\text { Soils have relatively higher plant } \\
\text { available water, crops are } \\
\text { well-watered }\end{array}$ & No change \\
\hline${ }^{1}$ Not observed in this study because of somewhat excessively to excessively drained soils in the domain.
\end{tabular}

Interfield differences in ET were less than or equal to intrafield differences in ET with some key exceptions caused by phenology or water limitations (Table 5). Observable differences in LAI (Figure 3) aligned with interfield differences in ET during the 7 August 2014, 16 June 2015, 2 July 2015, 11 Aug 2015, 1 July 2016, and 18 August 2016 missions. Sweet corn was planted the latest in all three years and, consequently, had low LAI and ET in June and early July images. Senescing potato crops and pearl millet cover crops with only partial canopy cover limited ET in August images. In the absence of observable differences in phenology, water limitations likely caused interfield differences in ET on 6 June 2014 and 2 July 2015. During the 6 June 2014 mission, fields P and W had very similar LAI values for field corn (Figure 3), though field P was planted three days earlier than field W. Field P had a mean ET of $0.18 \mathrm{~mm} \mathrm{hr}^{-1}$, while field $\mathrm{W}$ had a mean ET of $0.31 \mathrm{~mm} \mathrm{hr}^{-1}$ (Table 5). Water limitation on field P may have resulted from an absence of rain in the four days preceding the 6 June 2014 mission, which took place prior to irrigation initiation. Likewise, during the 2 July 2015 mission, fields L and $P$ had very similar LAI values for sweet corn (Figure 3), but field L had a mean ET of $0.12 \mathrm{~mm} \mathrm{hr}^{-1}$, while field $\mathrm{P}$ had a mean ET value of $0.47 \mathrm{~mm} \mathrm{hr}^{-1}$ (Table 5). Water limitation on field L may have resulted from an absence of rain and irrigation in the four days preceding the 2 July 2015 mission, as field L was irrigated on 2 July 2015 after the mission, while field P received $21 \mathrm{~mm}$ of irrigation over the four days prior to the flight. 
Table 5. Field ET estimates $\left(\mathrm{mm} \mathrm{hr}^{-1}\right)$.

\begin{tabular}{cccccccc}
\hline Mission & Date (DOY) & $\mathbf{H}$ & $\mathbf{G}$ & $\mathbf{P}$ & $\mathbf{L}$ & $\mathbf{E}$ & $\mathbf{W}$ \\
\hline 1 & 06 June 14 (157) & $0.36(0.02)$ & $0.35(0.04)$ & $0.18(0.04)$ & $0.35(0.02)$ & $0.34(0.04)$ & $0.31(0.04)$ \\
2 & 16 July 14 (197) & $0.76(0.02)$ & $0.73(0.02)$ & $0.78(0.02)$ & $0.77(0.02)$ & $0.68(0.02)$ & na \\
3 & 23 July 14 (204) & $0.67(0.01)$ & $0.66(0.01)$ & $0.65(0.01)$ & $0.65(0.01)$ & $0.63(0.01)$ & $0.64(0.01)$ \\
4 & 07 August 14(219) & $0.50(0.02)$ & $0.66(0.01)$ & $0.75(0.01)$ & $0.74(0.01)$ & $0.74(0.01)$ & $0.74(0.01)$ \\
5 & 16 June 15(167) & na & na & $0.59(0.04)$ & $0.48(0.06)$ & $0.79(0.01)$ & $0.72(0.02)$ \\
6 & 02 July 15 (183) & $0.73(0.01)$ & $0.55(0.05)$ & $0.47(0.01)$ & $0.12(0.05)$ & $0.71(0.03)$ & $0.75(0.01)$ \\
7 & 27 July 15(208) & $0.73(0.02)$ & $0.78(0.02)$ & $0.78(0.01)$ & $0.79(0.01)$ & $0.75(0.02)$ & na \\
8 & 11 August 15(223) & na & $0.52(0.02)$ & $0.45(0.02)$ & na & $0.44(0.03)$ & $0.37(0.02)$ \\
9 & 17 June 16(169) & $0.55(0.03)$ & $0.36(0.05)$ & $0.54(0.03)$ & $0.50(0.05)$ & $0.69(0.02)$ & $0.45(0.04)$ \\
10 & 01 July 16 (183) & $0.73(0.02)$ & $0.53(0.01)$ & $0.74(0.02)$ & $0.71(0.02)$ & $0.71(0.04)$ & $0.74(0.02)$ \\
11 & 01 August 16(214) & $0.74(0.01)$ & $0.73(0.01)$ & $0.68(0.01)$ & $0.70(0.01)$ & $0.73(0.01)$ & $0.70(0.02)$ \\
12 & 18 August 16(231) & na & $0.59(0.02)$ & $0.31(0.03)$ & $0.22(0.04)$ & $0.61(0.03)$ & $0.37(0.05)$ \\
\hline
\end{tabular}

\section{Discussion}

\subsection{Potential Precision Irrigation Benefits Depend on Crop Rotation}

Our findings suggest that precision irrigation benefits will be crop-specific, even on the same agricultural field. For example, variable rate irrigation guided by $\mathrm{EC}_{\mathrm{a}}$ mapping may lead to greater water conservation and productivity outcomes in potato and sweet corn rotations than field corn. In this study, potato and sweet corn rotations had stronger relationships between $\mathrm{ET}_{\mathrm{R}}$ and $\mathrm{EC}_{\mathrm{a}}$ than field corn on all six fields. Field corn may not be as responsive to precision irrigation as other crops because it has a deeper rooting profile than sweet corn and potatoes [56] and has also been genetically engineered over the past 50 years to have increased drought tolerance and improved water-use efficiency [57]. This idea of crop-specific precision irrigation applies where shallow-rooted, high water-demand crops are rotated with deep-rooted, water-efficient crops that may not be worth the time, cost, and effort required for precision irrigation interventions.

\subsection{Potential Precision Irrigation Benefits Depend on Intrafield Soil Variability}

Precision irrigation benefits will also depend on whether differences in plant available water content are significant enough to impact crop water use within a field. For example, $\mathrm{ET}_{\mathrm{R}}$ and $\mathrm{EC}_{\mathrm{a}}$ had strong relationships in pea-pearl millet rotations on field $W$, but were almost unrelated on field $H$, which has low variability in soil hydraulic properties [9]. A strong relationship between $\mathrm{ET}_{\mathrm{R}}$ and $\mathrm{EC}_{\mathrm{a}}$ indicates that the intrafield variability in plant available water content is significant enough to impact crop water use when irrigation is distributed uniformly over a field. Because the relationships between $\mathrm{ET}_{\mathrm{R}}$ and $\mathrm{EC}_{\mathrm{a}}$ were the strongest on fields $\mathrm{E}$ and $\mathrm{G}$, we suggest that these fields have the most significant intrafield plant water content variability and would benefit the most from precision irrigation if the crop type was constant. These fields also have the strongest variability in soil texture, field capacity, and organic matter content [9]. Conversely, because field $\mathrm{H}$ had the weakest relationships between $\mathrm{ET}_{\mathrm{R}}$ and $\mathrm{EC}_{\mathrm{a}}$, we argue that it offers a limited return on investment in precision irrigation interventions, regardless of the specific crop rotation. The coarse-textured, relatively homogenous soils in this study show minimal spatial variability in plant available water content which impacts impact crop water use within a field. We speculate that observing the relationships between ETR and $\mathrm{EC}_{\mathrm{a}}$ could be an even more powerful approach for informing irrigation management on fields with greater soil heterogeneity and more fine-grained soils than those in the Wisconsin Central Sands.

\subsection{Potential Precision Irrigation Benefits Depend on Existing Irrigation Practices}

Precision irrigation benefits will depend on existing conventional irrigation practices that amplify or diminish the spatial variability of crop water limitation. Irrigation practices already in place may diminish the observed variability in ET on a given field, which could potentially conceal or misinform the identification of precision irrigation benefits. For example, field $\mathrm{L}$ had a stronger relationship 
between $\mathrm{EC}_{\mathrm{a}}$ and $\mathrm{ET}_{\mathrm{R}}$ for potatoes and sweet corn than field P. Both fields $\mathrm{L}$ and $\mathrm{P}$ have strong relationships between $\mathrm{EC}_{\mathrm{a}}$ and soil hydraulic properties [9], are separated by only $\sim 100 \mathrm{~m}$, and were planted with sweet corn in 2015 and potatoes in 2016. However, field P received 28 and $78 \mathrm{~mm} \mathrm{yr}^{-1}$ more irrigation than field L in 2015 and 2016, respectively. We suggest that the increased irrigation on field P may have irrigated the relatively finer-textured portions of the field at higher rates than necessary and washed out intrafield differences in ET. Alternatively, decreased irrigation on field L may have under-irrigated the relatively coarser-textured portions of the field and amplified intrafield differences in ET. Both fields may be candidates for precision irrigation based on their soil heterogeneity, however specific interventions would differ based on current irrigation practices.

\subsection{Future Applications of HRMET}

A long-term goal of regional water managers is to have high-resolution estimates of ET available for irrigators to use in real-time irrigation management. Analyses are underway to implement an integrated data fusion approach and create high-resolution (30-m) daily maps of ET in the WCS by fusing Landsat, MODIS, and GOES satellite imagery data [58,59]. However, acquiring frequent cloud-free satellite imagery of cropping systems is a significant and ongoing challenge in the midwestern United States [60]. Thus, satellite-derived ET estimates are gap-filled during cloudy periods using the "self-preservation" ratio of actual to reference ET (i.e., crop coefficients) [17,61]. High-resolution estimates of ET using HRMET could be especially useful for validating satellite-based daily ET estimates. Because it is possible to capture thermal images by avoiding clouds with the aid of a deft pilot, we were able to estimate ET on cloudy days that would present gaps in satellite data. Using the HRMET model in conjunction with thermal and multiband imagery collected via remotely piloted aircrafts could further provide even more flexibility around cloud cover in regions like the Midwest United States. Additionally, the Monte Carlo approach we used facilitates an improved understanding of which meteorological drivers contribute to the uncertainty of ET estimates on a given day. Recent studies are attempting to separate high-resolution satellite fusion estimates of daily ET from different crops in close proximity to one another [58]. These research efforts could be even more informative to water managers by incorporating meteorological uncertainty into ET estimates from different crops in close proximity. HRMET provides a valuable tool to understand whether the uncertainty of ET estimates is greater than the differences in ET between different crops in close proximity. For example, in this study, the uncertainty of instantaneous ET estimates within a crop type was always greater than the differences in ET between crop types. Thus, though it is possible to separate the ET estimates by crop type, the magnitude of the differences between crops may not always be significant. Understanding these uncertainties by crop type and land cover will help planners and policymakers manage stakeholder expectations from precision irrigation and other conservation interventions that rely on satellite data for decision support.

\section{Conclusions}

Precision irrigation is gaining traction as a water conservation strategy that could maximize crop production and water-use efficiency while minimizing environmental impacts. Maps of $\mathrm{EC}_{\mathrm{a}}$, especially when paired with soil sampling or soil moisture monitoring, can help irrigators identify intrafield heterogeneity in plant available water content. Pairing $\mathrm{EC}_{\mathrm{a}}$ with maps of crop $\mathrm{ET}$ and the $\mathrm{ET}_{\mathrm{R}}$ index can further support irrigators in assessing the potential return on investment in precision irrigation technology for different fields and crops. We found that shallow-rooted crops like potatoes and sweet corn are more likely to benefit from precision interventions than deep-rooted crops bred for drought resistance (e.g., field corn). We also validated the HRMET model in potatoes, sweet corn, peas, and pearl millet, and demonstrated its usefulness for assessing crop water use and uncertainty in sandy, irrigated agroecosystems at the spatiotemporal scale necessary for validating future satellite-based efforts.

Combining high-resolution $\mathrm{EC}_{\mathrm{a}}$ and ET mapping could critically inform precision irrigation in rotational agroecosystems. Maps of crop ET and the $\mathrm{ET}_{\mathrm{R}}$ index can help irrigators assess the sensitivity 
of different crops to drought, develop irrigation management zones, and maximize the return on investment in precision irrigation technology. In this study, we demonstrated that relationships between dynamic crop water use $\left(\mathrm{ET}_{\mathrm{R}}\right)$ and plant available water content $\left(\mathrm{EC}_{\mathrm{a}}\right)$ are driven by $(1)$ crop type, where shallow-rooted crops exhibit greater intrafield variability in water use; (2) intrafield soil physical variability, which needs to be significant enough to impact ET; and (3) existing irrigation management, which can amplify or diminish water limitations. Further studies are needed to assess long-term water savings, water use efficiency, and the yield potential of precision irrigation interventions in rotational agroecosystems.

Author Contributions: Conceptualization, M.A.N., S.C.Z, C.J.K., and S.P.L.I.; Methodology, M.A.N., S.C.Z., E.G.B., and C.R.C.; Software, S.C.Z., M.A.N., C.R.C., and E.G.B.; Validation, M.A.N. and S.C.Z.; Formal analysis, M.A.N.; Investigation, M.A.N. and C.J.K.; Resources, C.J.K., E.G.B., and S.P.L.I.; Writing-original draft preparation, M.A.N.; Writing-review and editing, M.A.N., S.C.Z., E.G.B., C.R.C., C.J.K., and S.P.L.I.; Visualization, M.A.N., E.G.B., and C.R.C.; Supervision, C.J.K. and S.P.L.I.; Project administration, M.A.N. and C.J.K.; Funding acquisition, M.A.N., C.J.K., and S.P.L.I.

Funding: The research described in this study has been funded in part by the United States Environmental Protection Agency (EPA) under the Science to Achieve Results (STAR) Graduate Fellowship Program. EPA has not officially endorsed this publication and the views expressed herein may not reflect the views of the EPA. Additionally, this work is a product of research funded by the Wisconsin Department of Natural Resources (WDNR), University of Wisconsin Consortium for Extension and Research in Agriculture and Natural Resources, the United States Department of Agriculture Sustainable Agriculture Research and Education program, and the Smith Family and Wisconsin Potato Industry Board Distinguished Graduate Fellowships, and the David H. Smith Conservation Research Fellowship.

Acknowledgments: We also acknowledge Isherwood Farms, Eric Kruger, Matthew Ruark, Noah Feinstein, George Kraft, John Panuska, Paige Frautschy, Christopher Ester, Amy Sandel Ester, and Logan Ebert for assistance with research development, manuscript review, experimental logistics, statistics, field work, and airborne campaigns. We would also like to acknowledge John Jorgensen, Jeffrey Oimoen, and Gary Vetterli at the WDNR Aeronautics Section for flight logistics and services.

Conflicts of Interest: The authors declare no conflict of interest.

\section{Appendix A}

Table A1. LAI-EVI and height-EVI fits.

\begin{tabular}{|c|c|c|c|c|c|c|c|c|}
\hline \multirow[t]{2}{*}{ Crop Type } & \multirow{2}{*}{$\begin{array}{c}\text { Phenological } \\
\text { Variable }\end{array}$} & \multirow[t]{2}{*}{$n$} & \multirow{2}{*}{$\begin{array}{l}\text { Prediction } \\
\text { Model }\end{array}$} & \multicolumn{3}{|c|}{ Coefficients (Confidence Intervals) } & \multirow{3}{*}{$\begin{array}{c}\text { RMSE } \\
1.127\end{array}$} & \multirow{3}{*}{$\begin{array}{c}R^{2} \\
0.464\end{array}$} \\
\hline & & & & $a$ & $b$ & $c$ & & \\
\hline \multirow[t]{2}{*}{ Field corn } & $\operatorname{LAI}\left(\mathrm{m}^{2} \mathrm{~m}^{-2}\right)$ & 122 & $a x^{b}$ & $\begin{array}{c}3.986 \\
(3.581,4.391)\end{array}$ & $\begin{array}{c}1.308 \\
(0.935,1.681)\end{array}$ & - & & \\
\hline & $h(\mathrm{~m})$ & 96 & $a x^{b}+c$ & $\begin{array}{c}2.486 \\
(1.951,3.022)\end{array}$ & $\begin{array}{c}1.471 \\
(0.555,2.387)\end{array}$ & $\begin{array}{c}0.115 \\
(-0.526,0.755)\end{array}$ & 0.498 & 0.632 \\
\hline Sweet corn & $h(\mathrm{~m})$ & 123 & $a x+b$ & $\begin{array}{c}2.369 \\
(2.130,2.609)\end{array}$ & $\begin{array}{c}-0.1758 \\
(-0.321,-0.031)\end{array}$ & - & 0.391 & 0.762 \\
\hline Potato & $\operatorname{LAI}\left(\mathrm{m}^{2} \mathrm{~m}^{-2}\right)$ & 209 & $a x^{b}$ & $\begin{array}{c}4.675 \\
(4.379,4.971)\end{array}$ & $\begin{array}{c}0.6257 \\
(0.504,0.748)\end{array}$ & - & 1.140 & 0.431 \\
\hline Peas & $h(\mathrm{~m})$ & 29 & $a x+b$ & $\begin{array}{c}0.593 \\
(0.561,0.625)\end{array}$ & $\begin{array}{c}1.266 \\
(1.048,1.483)\end{array}$ & - & 0.053 & 0.952 \\
\hline \multirow[t]{2}{*}{ Pearl Millet } & $\operatorname{LAI}\left(\mathrm{m}^{2} \mathrm{~m}^{-2}\right)$ & 13 & $a x^{b}$ & $\begin{array}{c}1.739 \\
(0.526,2.952)\end{array}$ & $\begin{array}{c}0.393 \\
(-0.148,0.934)\end{array}$ & - & 0.401 & 0.393 \\
\hline & $h(\mathrm{~m})$ & 12 & $a x^{b}+c$ & $\begin{array}{c}3.633 \\
(-11.680,18.940)\end{array}$ & $\begin{array}{c}4.743 \\
(-0.969,10.460)\end{array}$ & $0.111(0.077,0.145)$ & 0.028 & 0.516 \\
\hline
\end{tabular}




\section{References}

1. Sadler, E.J.; Evans, R.G.; Stone, K.C.; Camp, C.R. Opportunities for conservation with precision irrigation. J. Soil Water Conserv. 2005, 60, 371-378.

2. Delgado, J.A.; Bausch, W.C. Potential use of precision conservation techniques to reduce nitrate leaching in irrigated crops. J. Soil Water Conserv. 2005, 60, 379-387.

3. Liakos, V.; Vellidis, G.; Tucker, M.; Lowrance, C.; Liang, X. A decision support tool for managing precision irrigation with center pivots. In Precision Agriculture'15; Wageningen Academic Publishers: Wageningen, The Netherlands, 2015; pp. 713-720. ISBN 9086862675.

4. Rezaei, M.; Saey, T.; Seuntjens, P.; Joris, I.; Boënne, W.; Van Meirvenne, M.; Cornelis, W. Predicting saturated hydraulic conductivity in a sandy grassland using proximally sensed apparent electrical conductivity. J. Appl. Geophys. 2016, 126, 35-41. [CrossRef]

5. Fortes, R.; Millán, S.; Prieto, M.H.; Campillo, C. A methodology based on apparent electrical conductivity and guided soil samples to improve irrigation zoning. Precis. Agric. 2015, 16, 441-454. [CrossRef]

6. Neely, H.L.; Morgan, C.L.S.; Stanislav, S.; Rouze, G.; Shi, Y.; Thomasson, J.A.; Valasek, J.; Olsenholler, J. Strategies for soil-based precision agriculture in cotton. In Autonomous Air and Ground Sensing Systems for Agricultural Optimization and Phenotyping; International Society for Optics and Photonics: Bellingham, WA, USA, 2016; Volume 9866, p. 98660K.

7. Pedrera-Parrilla, A.; Van De Vijver, E.; Van Meirvenne, M.; Espejo-Pérez, A.J.; Giráldez, J.V.; Vanderlinden, K. Apparent electrical conductivity measurements in an olive orchard under wet and dry soil conditions: Significance for clay and soil water content mapping. Precis. Agric. 2016, 17, 531-545. [CrossRef]

8. Islam, A.; Ahuja, L.R.; Garcia, L.A.; Ma, L.; Saseendran, A.S. Modeling the effect of elevated co (2) and climate change on reference evapotranspiration in the semi-arid central great plains. Trans. ASABE 2012, 55, 2135-2146. [CrossRef]

9. Nocco, M.A.; Ruark, M.D.; Kucharik, C.J. Apparent electrical conductivity predicts physical properties of coarse soils. Geoderma 2019, 335, 1-11. [CrossRef]

10. Haghverdi, A.; Leib, B.G.; Washington-Allen, R.A.; Ayers, P.D.; Buschermohle, M.J. Perspectives on delineating management zones for variable rate irrigation. Comput. Electron. Agric. 2015, 117, 154-167. [CrossRef]

11. Sudduth, K.A.; Kitchen, N.R.; Wiebold, W.J.; Batchelor, W.D.; Bollero, G.A.; Bullock, D.G.; Clay, D.E.; Palm, H.L.; Pierce, F.J.; Schuler, R.T. Relating apparent electrical conductivity to soil properties across the north-central USA. Comput. Electron. Agric. 2005, 46, 263-283. [CrossRef]

12. Hedley, C.B.; Yule, I.J. Soil water status mapping and two variable-rate irrigation scenarios. Precis. Agric. 2009, 10, 342-355. [CrossRef]

13. Hedley, C.B.; Yule, I.J. A method for spatial prediction of daily soil water status for precise irrigation scheduling. Agric. Water Manag. 2009, 96, 1737-1745. [CrossRef]

14. Gooley, L.; Huang, J.; Page, D.; Triantafilis, J. Digital soil mapping of available water content using proximal and remotely sensed data. Soil Use Manag. 2014, 30, 139-151. [CrossRef]

15. Ortuani, B.; Chiaradia, E.A.; Priori, S.; L'Abate, G.; Canone, D.; Comunian, A.; Giudici, M.; Mele, M.; Facchi, A. Mapping Soil Water Capacity Through EMI Survey to Delineate Site-Specific Management Units Within an Irrigated Field. Soil Sci. 2016, 181, 252-263. [CrossRef]

16. Campbell, G.S.; Norman, J.M. An Introduction to Environmental Biophysics; Springer: Berlin/Heidelberg, Germany, 1998; ISBN 0387949372.

17. Semmens, K.A.; Anderson, M.C.; Kustas, W.P.; Gao, F.; Alfieri, J.G.; McKee, L.; Prueger, J.H.; Hain, C.R.; Cammalleri, C.; Yang, Y. Monitoring daily evapotranspiration over two California vineyards using Landsat 8 in a multi-sensor data fusion approach. Remote Sens. Environ. 2016, 185, 155-170. [CrossRef]

18. Zipper, S.C.; Loheide, S.P., II. Using evapotranspiration to assess drought sensitivity on a subfield scale with HRMET, a high resolution surface energy balance model. Agric. For. Meteorol. 2014, 197, 91-102. [CrossRef]

19. Feddes, R.A.; Hoff, H.; Bruen, M.; Dawson, T.; de Rosnay, P.; Dirmeyer, P.; Jackson, R.B.; Kabat, P.; Kleidon, A.; Lilly, A. Modeling root water uptake in hydrological and climate models. Bull. Am. Meteorol. Soc. 2001, 82, 2797-2809. [CrossRef]

20. Zipper, S.C.; Soylu, M.E.; Booth, E.G.; Loheide, S.P., II. Untangling the effects of shallow groundwater and soil texture as drivers of subfield-scale yield variability. Water Resour. Res. 2015, 51, 6338-6358. [CrossRef] 
21. Watson, K.A.; Mayer, A.S.; Reeves, H.W. Groundwater availability as constrained by hydrogeology and environmental flows. Groundwater 2014, 52, 225-238. [CrossRef]

22. Kraft, G.J.; Clancy, K.; Mechenich, D.J.; Haucke, J. Irrigation effects in the northern lake states: Wisconsin central sands revisited. Groundwater 2012, 50, 308-318. [CrossRef]

23. Wisconsin Department of Natural Resources. The Ecological Landscapes of Wisconsin: An Assessment of Ecological Resources and Guide to Planning Sustainable Management; PUB-SS_1131L2015; Wisconsin Department of Natural Resources: Madison, WI, USA, 2015.

24. Kraft, G.J.; Mechenich, D.J. Groundwater Pumping Effects on Groundwater Levels, Lake Levels, and Streamflows in the Wisconsin Central Sands; Center for Watershed Science and Education, College of Natural Resources, University of Wisconsin-Stevens Point/Extension: Stevens Point, WI, USA, 2010.

25. Bradbury, K.; Fienen, M.; Kniffin, M.; Krause, J.; Westenbroek, S.M.; Leaf, A.T.; Barlow, P.M. Groundwater Flow Model for the Little Plover River basin in Wisconsin's Central Sands; Wisconsin Geological and Natural History Survey: Madison, WI, USA, 2017.

26. Fienen, M.N.; Bradbury, K.R.; Kniffin, M.; Barlow, P.M. Depletion Mapping and Constrained Optimization to Support Managing Groundwater Extraction. Groundwater 2018, 56, 18-31. [CrossRef]

27. Kustas, W.P.; Anderson, M.C.; Alfieri, J.G.; Prueger, J.H.; Geli, H.M.E.; Neale, C.M.U. Mapping evapotranspiration with high-resolution aircraft imagery over vineyards using one-and two-source modeling schemes. Hydrol. Earth Syst. Sci. 2016, 20, 1523.

28. Norman, J.M.; Kustas, W.P.; Humes, K.S. Source approach for estimating soil and vegetation energy fluxes in observations of directional radiometric surface temperature. Agric. For. Meteorol. 1995, 77, 263-293. [CrossRef]

29. Kustas, W.P.; Norman, J.M. A two-source energy balance approach using directional radiometric temperature observations for sparse canopy covered surfaces. Agron. J. 2000, 92, 847-854. [CrossRef]

30. Yang, Y.; Shang, S. A hybrid dual-source scheme and trapezoid framework-based evapotranspiration model (HTEM) using satellite images: Algorithm and model test. J. Geophys. Res. Atmos. 2013, 118, 2284-2300. [CrossRef]

31. Bastiaanssen, W.G.M.; Menenti, M.; Feddes, R.A.; Holtslag, A.A.M. A remote sensing surface energy balance algorithm for land (SEBAL). 1. Formulation. J. Hydrol. 1998, 212, 198-212. [CrossRef]

32. Feng, J.; Wang, Z. A satellite-based energy balance algorithm with reference dry and wet limits. Int. J. Remote Sens. 2013, 34, 2925-2946. [CrossRef]

33. Allen, R.G.; Tasumi, M.; Trezza, R. Satellite-based energy balance for mapping evapotranspiration with internalized calibration (METRIC)—Model. J. Irrig. Drain. Eng. 2007, 133, 380-394. [CrossRef]

34. Timmermans, W.J.; Kustas, W.P.; Andreu, A. Utility of an automated thermal-based approach for monitoring evapotranspiration. Acta Geophys. 2015, 63, 1571-1608. [CrossRef]

35. Serbin, S.P.; Singh, A.; McNeil, B.E.; Kingdon, C.C.; Townsend, P.A. Spectroscopic determination of leaf morphological and biochemical traits for northern temperate and boreal tree species. Ecol. Appl. 2014, 24, 1651-1669. [CrossRef]

36. Kang, Y.; Özdoğan, M.; Zipper, S.C.; Román, M.O.; Walker, J.; Hong, S.Y.; Marshall, M.; Magliulo, V.; Moreno, J.; Alonso, L. How universal is the relationship between remotely sensed vegetation indices and crop leaf area index? A global assessment. Remote Sens. 2016, 8, 597. [CrossRef]

37. Huete, A.; Justice, C.; Van Leeuwen, W. MODIS vegetation index (MOD13). Algorithm Theor. Basis Doc. 1999, 3, 213.

38. Boegh, E.; Soegaard, H.; Broge, N.; Hasager, C.B.; Jensen, N.O.; Schelde, K.; Thomsen, A. Airborne multispectral data for quantifying leaf area index, nitrogen concentration, and photosynthetic efficiency in agriculture. Remote Sens. Environ. 2002, 81, 179-193. [CrossRef]

39. Allred, B.; Daniels, J.J.; Ehsani, M.R. Handbook of Agricultural Geophysics; CRC Press: Boca Raton, FL, USA, 2008; ISBN 142001935X.

40. Sheets, K.R.; Hendrickx, J.M.H. Noninvasive Soil Water Content Measurement Using Electromagnetic Induction. Water Resour. Res. 1995, 31, 2401-2409. [CrossRef]

41. Corwin, D.L.; Lesch, S.M. Characterizing soil spatial variability with apparent soil electrical conductivity: I. Survey protocols. Comput. Electron. Agric. 2005, 46, 103-133. [CrossRef]

42. Daccache, A.; Knox, J.W.; Weatherhead, E.K.; Daneshkhah, A.; Hess, T.M. Implementing precision irrigation in a humid climate-Recent experiences and on-going challenges. Agric. Water Manag. 2015, 147, 135-143. [CrossRef]

43. Hedley, C.B.; Roudier, P.; Yule, I.J.; Ekanayake, J.; Bradbury, S. Soil water status and water table depth modelling using electromagnetic surveys for precision irrigation scheduling. Geoderma 2013, 199, $22-29$. [CrossRef] 
44. Kobayashi, H.; Ryu, Y.; Baldocchi, D.D.; Welles, J.M.; Norman, J.M. On the correct estimation of gap fraction: How to remove scattered radiation in gap fraction measurements? Agric. For. Meteorol. 2013, 174, 170-183. [CrossRef]

45. Baret, F.; Guyot, G. Potentials and limits of vegetation indices for LAI and APAR assessment. Remote Sens. Environ. 1991, 35, 161-173. [CrossRef]

46. Anderson, M.C.; Neale, C.M.U.; Li, F.; Norman, J.M.; Kustas, W.P.; Jayanthi, H.; Chavez, J. Upscaling ground observations of vegetation water content, canopy height, and leaf area index during SMEX02 using aircraft and Landsat imagery. Remote Sens. Environ. 2004, 92, 447-464. [CrossRef]

47. Murthy, V.; Grant, R.; Milford, J.; Oliphant, A.; Orlandini, S.; Stigter, K.; Wieringa, J. Agricultural meteorological variables and their observations. In Guide to Agricultural Meteorological Practices; WMO-134; WMO: Geneva, Switzerland, 2010; Chapter 2; pp. 1-35.

48. Allen, R.G.; Pereira, L.S.; Raes, D.; Smith, M. Crop evapotranspiration-Guidelines for computing crop water requirements-FAO Irrigation and drainage paper 56. FAO Rome 1998, 300, 6541.

49. Walter, I.A.; Allen, R.G.; Elliott, R.; Jensen, M.E.; Itenfisu, D.; Mecham, B.; Howell, T.A.; Snyder, R.; Brown, P.; Echings, S. ASCE's standardized reference evapotranspiration equation. In Watershed Management and Operations Management 2000; Amer Society of Civil Engineers: Reston, VA, USA, 2000; pp. 1-11.

50. Nocco, M.A.; Kraft, G.J.; Loheide, S.P.; Kucharik, C.J. Drivers of potential recharge from irrigated agroecosystems in the wisconsin central sands. Vadose Zone J. 2018, 17. [CrossRef]

51. Shuttleworth, W.J.; Wallace, J.S. Evaporation from sparse crops-an energy combination theory. Q. J. $R$. Meteorol. Soc. 1985, 111, 839-855. [CrossRef]

52. Camillo, P.J.; Gurney, R.J. A resistance parameter for bare-soil evaporation models. Soil Sci. 1986, 141, 95-105. [CrossRef]

53. Rawls, W.J.; Ahuja, L.R.; Brakensiek, D.L. Estimating soil hydraulic properties from soils data. In Indirect Methods for Estimating the Hydraulic Properties of Unsaturated Soils; University of California: Riverside, CA, USA, 1992; pp. 329-340.

54. Newson, R. Parameters behind "nonparametric" statistics: Kendall's tau, Somers'D and median differences. Stata J. 2002, 2, 45-64. [CrossRef]

55. Brisson, N.; Itier, B.; L'Hotel, J.C.; Lorendeau, J.Y. Parameterisation of the Shuttleworth-Wallace model to estimate daily maximum transpiration for use in crop models. Ecol. Modell. 1998, 107, 159-169. [CrossRef]

56. Sanford, S.; Panuska, J. Irrigation Management in Wisconsin. Univ. Wisconsin Coop. Ext. Publ. 2015. Available online: https://fyi.extension.wisc.edu/cropirrigation/files/2015/03/IrrigationManagement.pdf (accessed on 5 December 2015).

57. Reyes, A.; Messina, C.D.; Hammer, G.L.; Liu, L.; van Oosterom, E.; Lafitte, R.; Cooper, M. Soil water capture trends over 50 years of single-cross maize (Zea mays L.) breeding in the US corn-belt. J. Exp. Bot. 2015, 66, 7339-7346. [CrossRef] [PubMed]

58. Yang, Y.; Qiu, J.; Zhang, R.; Huang, S.; Chen, S.; Wang, H.; Luo, J.; Fan, Y. Intercomparison of Three Two-Source Energy Balance Models for Partitioning Evaporation and Transpiration in Semiarid Climates. Remote Sens. 2018, 10, 1149. [CrossRef]

59. Cammalleri, C.; Anderson, M.C.; Kustas, W.P. Upscaling of evapotranspiration fluxes from instantaneous to daytime scales for thermal remote sensing applications. Hydrol. Earth Syst. Sci. 2014, 18, 1885-1894. [CrossRef]

60. Zhu, L.; Radeloff, V.C.; Ives, A.R. Improving the mapping of crop types in the Midwestern US by fusing Landsat and MODIS satellite data. Int. J. Appl. Earth Obs. Geoinf. 2017, 58, 1-11. [CrossRef]

61. Anderson, M.C.; Allen, R.G.; Morse, A.; Kustas, W.P. Use of Landsat thermal imagery in monitoring evapotranspiration and managing water resources. Remote Sens. Environ. 2012, 122, 50-65. [CrossRef]

(C) 2019 by the authors. Licensee MDPI, Basel, Switzerland. This article is an open access article distributed under the terms and conditions of the Creative Commons Attribution (CC BY) license (http://creativecommons.org/licenses/by/4.0/). 